\title{
Bioremediation of Petroleum Hydrocarbon-Polluted Mangrove Swamps Using Nutrient Formula Produced From Water Hyacint (Eicchornia crassipes)
}

\author{
${ }^{1}$ Frank Anayo Orji, ${ }^{2}$ Abiye Anthony Ibiene and ${ }^{2}$ Phillip O. Okerentugba \\ ${ }^{1}$ Department of Biotechnology, Enzymes and Genetics Division, \\ Federal Institute of Industrial Research, Oshodi, PMB 21023, Ikeja Lagos State, Nigeria \\ ${ }^{2}$ Department of Microbiology, Faculty of Science, \\ University of Port Harcourt PMB 5323, Port Harcourt, Rivers State, Nigeria
}

Received 2012-08-21, Revised 2013-02-15; Accepted 2013-08-31

\begin{abstract}
Laboratory-scale studies were carried out using a nutrient formula produced from Eicchornia crassipes plant to achieve bioremediation of crude oil impacted mangrove soil. In a 70 day study, the culturable heterotrophic bacterial population of the Eichhornia crassipes recipe increased from $6.26 \times 10^{5} \mathrm{Cfu} / \mathrm{g}$ to $2.69 \times 10^{7} \mathrm{Cfu} / \mathrm{g}$. The control set-up had its total culturable bacterial count increased from $5.76 \times 10^{5} \mathrm{Cfu} / \mathrm{g}$ to $1.24 \times 10^{6} \mathrm{Cfu} / \mathrm{g}$. Statistical analyses showed significant difference for the two conditions $(\mathrm{p} \geq 0.05)$. The total culturable heterotrophic fungal count in the Eichhornia crassipes recipe treatment increased from $5.36 \times 10^{5} \mathrm{Cfu} / \mathrm{g}$ to $2.50 \times 10^{7} \mathrm{Cfu} / \mathrm{g}$ respectively. The total culturable hydrocarbon utilising bacteria in Eichhornia crassipes treated polluted mangrove soil increased from $2.52 \times 10^{4} \mathrm{Cfu} / \mathrm{g}$ to $3.81 \times 10^{7} \mathrm{Cfu} / \mathrm{g}$. Statistical analyses showed significant difference at $\mathrm{p} \geq 0.05$ level for the two conditions (Eicchornia crassipes nutrient treated soil and control). The total culturable hydrocarbon utilising fungal counts increased significantly for both the control and Eichhornia crassipes treatment. There was no regular trend in $\mathrm{pH}$ changes in all the conditions. The conductivity value of the Eichhornia crassipes recipe treated soil decreased progressively. Phosphate, nitrate, \%total organic carbon, Total Hydrocarbon Content (THC). Studies using Gas chromatographic analyses showed that in the Eichhornia crassipes recipe treated polluted mangrove soil, $0,58.92$ and $75.36 \%$ were lost at zero hour, 28 th day and 70 th day respectively. In addition, in the control experimental set-up, $0,7.14$ and $13.42 \%$ of TPH were lost at zero hour, 28th day and 70th day respectively. There was no significant difference between the control experiment and Eichhornia crassipes $(\mathrm{p}=0.054)$. The use of organic nutrient sources such Eichhornia crassipes recipe/nutrient powder is of good use as source of limiting nutrient needed for bioremediation of crude oil impacted medium.
\end{abstract}

Keywords: Bioremediation, Nutrient Formula/Powder From Water Hyacinth, Petroleum Hydrocarbon Pollution, Biotechnology, Mangrove Swamps, Niger Delta

\section{INTRODUCTION}

Spillage of petroleum hydrocarbons either by accident or vandalization causes significant environmental pollution (Mukherjee and Bordoloi, 2010). Crude petroleum oil and its derivatives released in the environment either accidentally or deliberately pose problems of increasing magnitude throughout the world (Okoh and Trejo-Hernandez, 2006). Furthermore, these problems are more aggravated because of the expensive disposal methods (Rahman et al., 2003; Das and Mukherjee, 2007). The

Corresponding Author: Frank Anayo Orji, Department of Biotechnology, Enzymes and Genetics Division, Federal Institute of Industrial Research, Oshodi, PMB 21023, Ikeja Lagos State, Nigeria 
Niger Delta is a wetland containing a number of ecological zones: sandy coastal ridge barriers, mangroves, freshwater permanent and seasonal swamp forests and lowland rain forests.

The Niger Delta Mangrove Swamps provide grounds for commercial fishing, timber production, biotechnologically important microorganisms. However, pollution caused by petroleum and its byproducts/derivatives has greatly impacted negatively on the Mangrove swamps leading reduction in seafood output, increased food security challenges, reduction in biodiversity of mangrove biota, youth restiveness and violence in this region. The majority of the population depend largely on food products (Periwinkles, oysters, in the mangroves in the Niger Delta. The mangroves provide ecological protection against tsunamis, erosion. It provides herbs with pharmacological benefits. Today, mangrove forests and swamps are among the most threatened habitats in the Niger Delta. The mangrove Environment is disappearing at an accelerated rate, yet with little public notice and research attention. Lenticels in the exposed portions of the mangrove roots are highly susceptible to clogging by crude oil and other pollutants, attacks by parasites and prolonged flooding from artificial dykes or causeways. Petroleum hydrocarbon pollution of mangrove swamps has greatly endangered the Niger Delta mangrove ecosystem. This has led to increased toxicity and bioaccumulation of Petroleum hydrocarbon in the seafoods from the mangroves (Oudot et al., 1981; Vandermeulen and Gilfillan, 1985; Odokuma and Dickson, 2003). Among the various strategies adopted to clean petroleum oil-contaminated soil, bioremediation is recognized as one of the effective and inexpensive technologies (Das and Mukherjee, 2007). This approach involves supplying hydrocarbon-degrading efficient microorganisms to degrade target compounds, along with appropriate nutrients, to the subsurface (petroleum oil-contaminated sites). It should be noted that site remediation technology must be simple and costeffective for both industrialized as well as for developing countries to be able to sort out and resolve this menace. Bioremediation of complex hydrocarbons usually requires the co-operation of more than a single species because the individual microorganism can metabolize only a limited range of hydrocarbon substrates/fractions (Mukherjee and Bordoloi, 2010). Bioremediation is an effective process to remediate petroleum oil contaminated mangrove ecosystem (Eziuzor and Okpokwasili, 2009).

However, the use of NPK fertilizer as source of limiting nutrients for bioremediation posses great environmental challenges including eutrophication, toxicity to marine lives including fishes. Above all, it not cost effective when compared with the use of waste materials or organic fertilizers. In response to these existing challenges encountered with the use of NPK fertilizers during remediation of polluted aquatic environment, this study used nutrient formula/recipe for the bioremediation of Crude-oil polluted Mangrove swamps in the Niger Delta. The objectives of the study were; to determine the possibility of developing a fertilizer/nutrient formula/recipe for bioremediation from Water hyacinth (Eicchornia crassipes), an invasive/problematic species that has become a nuisance in water ways of the Niger Delta and other parts of the world and to determine the effectiveness of the produced water hyacinth recipe/powder in the bioremediation of crude oil polluted mangrove in the Niger Delta, Federal Republic of Nigeria.

\section{MATERIALS AND METHODS}

\subsection{Study Area}

The hydrocarbon polluted soil was excavated from mangrove swamp at Elibrada, Emuoha Local Government Area of Rivers State, Nigeria. The mangrove swamp is accessible through Elibrada junction. The mangrove swamp links Emuoha and Kalabari. This site was selected due to high level of pollution as a result of oil spillage from a pipeline over two decades. The predominant mangrove plant in this area is Rhizophora racemosa as identified by Dr. Godfrey Akani of the Department of Applied and Environmental Biology, Rivers State University of Science and Technology, Port Harcourt, Nigeria. The major occupation of Elibrada people is fishing in the mangrove and agricultural/land farming.

\subsection{Sample Collection}

The soil sample was collected with a spade into a plastic pail which was cleaned with cotton wool soaked in 70\% alcohol (Eziuzor and Okpokwasili, 2009). Four sampling points were sampled and the soils from the sampling points were mixed/lumped together after excavation. The excavated soil was transported to the Environmental Microbiology laboratory of the University of Port Harcourt for bioremediation study. Co-ordinates of the sampling points were also determined using Global Positioning System (GPS). The co-ordinates of the sampling points were: $453^{\prime} 53.990$ "N 650'43.745"'E and 4'5353.874'N; 650'43.564'E for soil sampling points 1 and 2(SS 01 and SS 02) respectively. The sampling Co-ordinates for soil sampling points 3 and 4 (SS 03 and SS 04) were 454'59.990”N; 620’43.745”E and 454'56.886'N 657'43.775''E respectively. 


\subsection{Soil Contamination}

The Elibrada mangrove has been contaminated by petroleum hydrocarbon before the time of the study. However, $50 \mathrm{~mL}$ sec of Bonny light crude oil was poured in each treatment cell/pot containing $500 \mathrm{~g}$ of the mangrove soil (including the controls). The aim of this further contamination was to simulate condition of a major spill (Odokuma and Dickson, 2003). The polluted soil was at this point sampled for baseline studies. Bonny light crude oil used in this study was obtained from Shell Petroleum Development Company of Nigeria (Rumuobiakani, Port Harcourt, Nigeria).

\subsection{Preparation of the Water Hyacinth Recipe Nutrient Formula/Fertilizer/Recipe}

The water hyacinth used for this study was obtained from Choba River, accessible through Choba cattle Market, Port Harcourt. They were identified as Water hyacinth (Eichhornia crassipes) by Dr. Godffrey Akani of the Department of Applied Environmental Biology, Rivers State University of Science and Technology, Port Harcourt. Large quantity of the water hyacinth was harvested and transported to the Environmental Microbiology Laboratory, University of Port Harcourt. The water hyacinth recipe was chopped into pieces and air-dried. The dried water hyacinth was grinded with local mortar and pestle and the organic fertilizer in powdery form was stored for use during the bioremediation experiment.

\subsection{Experimental Design}

This is a laboratory scale experiment carried out in plastics pots as described in Table 1. The decision to use 50 grams of the water hyacinth nutrient for 500 grams of the polluted soil was based on findings from preliminary investigation.

\subsection{Bioremediation Study}

The polluted soils in plastic pots were amended with $50 \mathrm{~g}$ of recipe/powder produced from water hyacinth. The control was never amended with nutrient. Sampling for laboratory studies started immediately after the soils were amended with nutrients. This is called zero (0) day or zero hour study. The water hyacinth nutrient powder treated polluted soil and control were regularly turned using different hand trowels to avoid cross-contamination of Petroleum hydrocarbon fractions in both sets (1 and 2).
Table 1. Bioremediation experimental design of the study

\begin{tabular}{ll}
\hline Experimental group & Test experiment \\
\hline Set 1 & $\begin{array}{l}500 \mathrm{~g} \text { of polluted soil }+50 \mathrm{~g} \text { of sterile } \\
\text { water hyacinth recipe/powder }\end{array}$ \\
Set 2 (Control) & $500 \mathrm{~g}$ of polluted soil + no nutrient
\end{tabular}

Each Experimental group had three (3) replicates

Samples were taken for laboratory analyses in two (2) weeks intervals at 14 th day, 28th day, 42nd day, 56th day and 70th day.

\subsection{Monitoring of Bioremediation/ Biodegradation Studies}

The bioremediation of petroleum hydrocarbons in the different experimental designs/set-up was studied/monitored by withdrawing samples before initiation of the experiment i.e., baseline and at time zero and subsequently at the 14th, 28th, 42nd, 56th and 70th days of the experiment for the following analyses.

\subsection{Microbiological Analysis}

\subsubsection{Enumeration of Total Culturable Heterotrophic Bacteria (TCHB)}

Total culturable heterotrophic bacterial count present in the 3 different groups was determined at zero hour, 14th, 28th, 42nd, 56th day and 70th day of the experiment. The spread plate method on nutrient agar (Antech Laboratories LTD) was used. Swamp soil suspensions were prepared by 10 fold serial dilutions with $1 \mathrm{~g}$ of soil, using normal saline as diluents. $0.1 \mathrm{~mL}$ aliquots of appropriate dilutions were spread on triplicates of sterile nutrient agar. The plates were incubated for period of $18-48 \mathrm{~h}$ in the incubator at $28^{\circ} \mathrm{C}$. Colonies that formed during this incubation period were counted using this formula:

$$
\frac{\text { No of Colonies } \times \text { Dilution Factor }}{\text { Amount used }}
$$

Values were expressed as colony forming units per gram $(\mathrm{Cfu} / \mathrm{g})$. Enumeration of total heterotrophic bacteria was carried out using the stated procedures which have been previously reported (Chikere et al., 2009).

\subsection{Enumeration of Total Culturable Heterotrophic Fungi (TCHF)}

The medium of choice was the Potato Dextrose Agar, (PDA) with $10 \%$ tartaric acid using the spread plate method. The medium was prepared according to the manufacture's (O×oid LTD) instruction and sterilized at 
$121^{\circ} \mathrm{C}, 15 \mathrm{psi}$ and $15 \mathrm{~min}$. before dispensing into sterile Petri plates. A $0.1 \mathrm{~mL}$ aliquot of appropriate dilutions (Normal saline diluent) of sample was inoculated unto the media. The plates were incubated in for 5-7 days at room temperature and colonies formed were counted and expressed as $\mathrm{Cfu} / \mathrm{g}$.

\subsection{Enumeration of Total Culturable Hydrocarbon Utilizing Bacteria (TCHUB)}

The enumeration of Total Culturable Hydrocarbon Utilizing Bacteria (TCHUB) was done by using the vapour phase method (Atuanya and Ibeh, 2004). Appropriate dilutions of the samples withdrawn from the two different conditions of $0 \mathrm{~h} ., 14,28,42,52$ and 70 days of analyses were inoculated into modified Mineral Salt Medium (MSM). The culture medium components (MSM) were $0.42 \mathrm{~g}$ of $\mathrm{MgSO}_{4} .7 \mathrm{H}_{2} \mathrm{O}, 0.297 \mathrm{~g}$ of $\mathrm{KCl}$, $0.85 \mathrm{~g}$ of $\mathrm{KH}_{2} \mathrm{PO}_{4}, 0.424 \mathrm{~g}$ of $\mathrm{NaNO}_{3}, 1.27 \mathrm{~g}$ of $\mathrm{K}_{2} \mathrm{HPO}_{4}$, $20.12 \mathrm{~g} \mathrm{NaCl}, 250$ milligrams of Amphotericin B (sold as Fungizone) and $20 \mathrm{~g}$ of Agar powder (Oxoid, Basingstoke, Hants, United Kingdom). These were weighed out and hydrated in $1000 \mathrm{~mL}$ of sterile distilled water in an Erlenmeyer flask. The medium was sterilized by autoclaving at $121^{\circ} \mathrm{C}, 15 \mathrm{Psi}$ for $15 \mathrm{~min}$. before dispensing into sterile Petri dishes. The gelled Mineral Salt Agar (MSA) was inoculated with appropriate dilutions of the swamp soil sample. Filter paper (Whatman No 1) was saturated with bonny light crude oil and the crude oil impregnated papers were aseptically placed onto the covers of Petri dishes and inverted. The hydrocarbon saturated filter papers supply hydrocarbon by vapour-phase transfer to the inoculums (Amanchukwu et al., 1989a; 1989b; Chikere and Chijioke-Osuji, 2006). The plates were incubated at $28^{\circ} \mathrm{C} \pm 2^{\circ} \mathrm{C}$ for seven (7) days and colonies were counted from triplicates and mean values were recorded in colony forming units per gram $(\mathrm{Cfu} / \mathrm{g})$.

\subsection{Enumeration of Total Culturable Hydrocarbon Utilizing Fungi Count (TCHUF)}

Enumeration of total culturable hydrocarbon utilizing fungi was done using Mineral Salt Agar (MSA) containing $10 \mathrm{~g}$ of $\mathrm{NaCl}, 0.45 \mathrm{~g}$ of $\mathrm{MgSO}_{4} 7 \mathrm{H}_{2} 0,0.42 \mathrm{~g}$ $\mathrm{KCl}, 0.29 \mathrm{~g}$ of $\mathrm{KH}_{2} \mathrm{PO}_{4}, 0.86 \mathrm{~g}$ of $\mathrm{Na}_{2} \mathrm{HPO}_{4}, \mathrm{H}_{2} \mathrm{O}, 0.43 \mathrm{~g}$ of $\mathrm{NaNO}_{3}$ and $25.0 \mathrm{~g}$ of Agar powder in $1000 \mathrm{~mL}$. The medium was sterilized by autoclaving at $121^{\circ} \mathrm{C}$ for 15 min, 10 Psi. Crude oil (Bonny light) served as both the sole carbon and energy sources. Three replicate plates inoculated by spread plating were inverted over sterile filter papers moistened with sterile crude oil, which were placed on the lid of Petri dish covers (Chukwura et al., 2005). The crude oil used was bonny light and the compounded medium for the hydrocarbon utilizing fungal count was amended with 250 milligrams of Chloramphenicol and tetracycline (Chikere and Chijioke-Osuji, 2006). Incubation was within 5-7days at $28 \pm 2{ }^{\circ} \mathrm{C}$ (Okpokwasili and Amanchukwu, 1988).

\subsection{Characterisation and Identification of Hydrocarbon Utilising Bacterial and Fungal Species}

The identification of hydrocarbon utilising bacterial was based on biochemical characterisation such as sugar and alcohol sugars fermentation tests, citrate, catalase, indole utilisation, methyl red, Voges-prauskauer, starch hydrolyses, oxidase reaction. The macroscopic colonial appearances of fungal growth in plates were observed and recorded. The macroscopic examinations were based on texture of the colony, colony size, pigmentation, time of growth, color on the reverse side of plate and margin of colony (Chukwura et al., 2005). A drop of lactophenol cotton blue was placed on a grease free, scratch-free glass slide (Mbakwem-Aniebo and Ezekwem, 2010). A small portion of the fungal growth was picked with a wire loop and teased out using a mounting needle. The preparation was covered with a cover slip (Chukwura et al., 2005). The slide was observed under $\times 10$ and $\times 40$ objective lenses. Observed characteristics were recorded and compared with the established identification keys of (Barnett and Hunter, 1972).

\subsection{Physico-Chemical Analyses}

\subsection{1.pH Measurement (pH Meter Electrometric Method)}

The $\mathrm{pH}$ of the samples withdrawn at baseline, zero hour, 14, 28, 42, 56 and 70th day of the study was determined using a digital $\mathrm{pH}$ meter (Jenway 3015, United Kingdom). At each point, three values were obtained and the mean of the values was used.

\subsection{Conductivity Measurement}

Conductivity of withdrawn samples was measured with a conductivity meter (Jenway 4010, United Kingdom) during the period of the experiment. The conductivity values were measured in $\mu \mathrm{s} / \mathrm{cm}$ and it gives a surrogate value of level of salinity and Total Dissolved Solids (TDS). 


\subsection{Measurement of Nitrate $\left(\mathrm{NO}_{3}^{-}\right)$Level of Amended Polluted Soil}

The brucine method was used. One $(1 \mathrm{~mL})$ of soil filtrate was measured into a clean test tube and $1 \mathrm{~mL}$ of distilled water was measured into a clean test tube and one $(1 \mathrm{~mL})$ of distilled water was measured into another test tube as blank solution. About $0.5 \mathrm{~mL}$ of brucine reagent was gently introduced into both test tubes. Two $(\mathrm{mL})$ of concentrated sulphuric acid was then added and shaken to homogenize. The resulting solution was allowed to cool to room temperature. The solution turned yellow and was measured at $470 \mathrm{~nm}$ on spectrophotometer (UNEP, 2004).

\subsection{Determination of Phosphate Content of the Amended Polluted Soil}

The method used was the colourimetric method as described in United Nations Environmental Programme (UNEP, 2004). One-tenth of 2.5\% glacial acetic acid was prepared was prepared and used for the extraction of phosphate in $250 \mathrm{~mL}$ capacity conical flask. The mixture was stirred for $10 \mathrm{~min}$. Fifty $(\mathrm{mL})$ sample extract was pipetted into a clean conical flask. This aliquot is autoclaved with $\mathrm{K}_{2} \mathrm{~S}_{2} \mathrm{O}_{8}$ and $\mathrm{H}_{2} \mathrm{SO}_{4}$ for $30 \mathrm{~min}$ at $121^{\circ} \mathrm{C}$, (5 mLs) of ammonium molybdbate was added to the autoclaved mixture to form heteropoly molybdophosphoric acid and is reduced with stannous chloride in an aqueous sulphuric acid medium, at $30^{\circ} \mathrm{C}$, to form a molybdenum blue complex. The resulting blue colour is measured spectrophotometrically at $660 \mathrm{~nm}$ and compared to identically prepared standard (water). The detection limit of this method is $0.001 \mathrm{mg} \mathrm{L}^{-1}$ (UNEP, 2004).

\subsection{Proximate Analyses of the Water Hyacinth Nutrient Powder}

The produced Water hyacinth nutrient powder was analysed for $\mathrm{pH}$, conductivity. Nitrate and Phosphate concentrations were also studied to determine the amount of the two limiting nutrients required for microbial remediation of polluted sites. The methods used for determination of these four parameters are still the procedures for the determination of $\mathrm{pH}$, conductivity, Nitrate and Phosphate concentrations in the amended polluted soil under-going remediation.

\subsection{Percentage Total Organic Carbon (\%TOC) Determination}

Total organic carbon is an alternative analytical method for measuring petroleum hydrocarbons using the wet oxidation technique as previously reported by (Nelson and Sommers, 1975). One gram of the sample was transferred into a clean Pyrex conical flask. Five milliliters $(\mathrm{mLs})$ potassium chromate solution and milliliters $(7.5 \mathrm{mLs})$ of concentrated sulphuric acid were added. The mixture was heated on an electrothermal heater for $15 \mathrm{~min}$. to reflux. The sample was cooled to room temperature and diluted to $100 \mathrm{mLs}$ with distilled water. Twenty five mLs of the sample solution was titrated with 0.2 molar ferrous ammonium sulphate using Ferrion as indicator. A blank containing oxidant (Potassium chromate) and sulphuric acid was titrated as in the sample and the titre value was recorded. Calculation was as follows:

$\%$ TOC $=\frac{\text { Titre value of blank }- \text { sample titre }}{\text { sample weight }} \times 0.003 \times 100$

\subsection{Total Hydrocarbon Content (THC)}

Five grams of soil sample was weighed into a beaker and $10 \mathrm{mLs}$ of xylene was added under cork cover for 30 min. Aliquot of the extract was placed in the infrared spectrophotometer analyzer. The Total Hydrocarbon (THC) value was determined by comparism to a calibration curve constructed from dilutions of a stock solution of a 1:1 bonny light crude and bonny medium. The Ultraviolet light spectrophotometric measurement was at $420 \mathrm{~nm}$ (UNEP, 2004; Osuji and Ezebuiro, 2006).

\subsection{Total Petroleum Hydrocarbon (TPH)}

\subsubsection{Extraction}

Five grams portion of soil sample was weighed out and $0.1 \mathrm{mg}$ was weighed out and transferred into extraction vessels. Fifty milliliters of acetone was added and the vessel was closed. The vessel was heated lender $200 \mathrm{psi}$, temperature of $150^{\circ} \mathrm{C}$, time of $15 \mathrm{~min}$. The vessels were at this point allowed to cool to room temperature. The vessels were opened at room temperature and five grams of sodium sulfate was added. The mixture was gently swirled. The extract mixture filtered through ashless filter paper rinsing and washing the sediment with acetone into a bigger container (Saari et al., 2007).

\subsection{Preparation of the Extracts for the Analysis}

Before GC-FID measurement, all extracts volume was adjusted to $(20 \mathrm{mLs})$ with $(20 \mathrm{mLs})$ hexane solution to prevent possible change in concentration of the 
extracted solutions because of evaporation losses of solvent mixtures during an extraction stage. Polar compounds, such as vegetable oils, animal fats were then removed by solid phase extraction under silica gel (florisil) (Saari et al., 2007).

\subsection{Calibration Checks and Instrument Precision}

Calibration was done using Bonny light Crude oil, Acetone and Mixture of Bonny light crude and Acetone. The Gas Chromatography machine and peak sum method can only detect $\geq \mathrm{C}_{10}$.

\subsection{Gas Chromatography-Flame Ionization Detection System}

The extracts were analyzed by gas chromatography, using Hp Agilent 6890 gas chromatography (Agilent technologies, 610 Wharfdale Road, Wokingham, Berkshire, United Kingdom) equipped with a FID detector, an Agilent 7673 auto sampler and 5 capillary column $(15 \mathrm{~m} \times 0.25 \mathrm{~mm})$ with a nominal film thickness of $0.25 \mu \mathrm{m}$, splitless injection method (all in batch). Injection volume was $1 \mu \mathrm{L}$ and injection temperature was $330^{\circ} \mathrm{C}$. Helium was used as a carrier gas $\left(2 \mathrm{~mL} \mathrm{~min}^{-1}\right)$. The column was held at $35^{\circ} \mathrm{C}$ for $1.50 \mathrm{~min}$. The temperature was increased from $15^{\circ} \mathrm{C} \mathrm{min}^{-1}$, to $310^{\circ} \mathrm{C}$ $\mathrm{min}^{-1}$ and held for $10 \mathrm{~min}$. This enabled complete run within $27 \mathrm{~min}$. The amount of Total Petroleum Hydrocarbon (THP) was then determined as a sum total of resolved and unresolved components eluted from the GC capillary column between retention times of 5 to 35 min. This method called peak sum calculates TPH by summing up all components of crude oil from $\mathrm{C} 10$ and upwards. Real values of TPH were calculated as product of raw data on FID table or graph and dilution factor used for each sample (Saari et al., 2007).

\subsection{Calculation of Percentage Loss in THC/TPH}

Percentage loss in THC and TPH was calculated using the formula below:

$$
\% \text { Loss in } \mathrm{TPH} / \mathrm{THC}=\frac{\text { Concentrationat a point-Conc. at time zero }}{\text { Concentration at time zero }} \times 100
$$

\subsection{Statistical Analysis}

Statistical analyses were carried out using Statistical Package For Social Sciences (SPSS, Version 17.0). Analysis Of Variance (ANOVA), P-values and tests of significance were carried out at $95 \%$ level of confidence using statistical package for social sciences. P-Values were used to determine the significance levels between treatment and control.

\section{RESULTS}

\subsection{Baseline Studies}

The initial physico-chemical and microbiological characteristics of the crude-oil polluted mangrove soil are documented in Table 2. The changes in the populations of heterotrophic and hydrocarbon utilizing bacteria and fungi are presented in Fig. 1-4.

\section{DISCUSSION}

\subsection{Baseline Studies}

The initial physico-chemical and microbiological characteristics of the crude-oil polluted mangrove soil are documented in Table 2 . The $\mathrm{pH}$, conductivity, nitrate, phosphate and percentage total organic carbon were $7.5 \pm 0.04,2380 \pm 3.12,10.52 \pm 0.286,8.11 \pm 0.021$, $3.30 \%$ respectively. The Total Petroleum hydrocarbon and Total hydrocarbon content were $12934.75 \pm 00$ and $14102.22 \pm 0.04$ respectively. The total culturable heterotrophic bacterial count, total culturable heterotrophic fungal count, total culturable hydrocarbon utilizing bacterial count, total culturable hydrocarbon utilizing fungal count were $6.1 \times 10^{5} \pm 0.004 \mathrm{Cfu} / \mathrm{g}$, $4.8 \times 10^{5} \pm 0.111 \quad \mathrm{Cfu} / \mathrm{g}, \quad 3.5 \times 10^{4} \pm 0.025 \quad \mathrm{Cfu} / \mathrm{g}$, $2.6 \times 10^{4} \pm 0.025 \mathrm{Cfu} / \mathrm{g}$ respectively (Table 2 ).

\subsection{Microbial Dynamics}

The total culturable heterotrophic bacterial counts in the water hyacinth powder treated polluted mangrove soil were $5.8 \times 10^{5} \mathrm{Cfu} / \mathrm{g}, 7.5 \times 10^{5} \mathrm{Cfu} / \mathrm{g}, 2.09 \times 10^{6} \mathrm{Cfu} / \mathrm{g}$, $2.90 \times 10^{7} \mathrm{Cfu} / \mathrm{g}, 2.43 \times 10^{7} \mathrm{Cfu} / \mathrm{g}, 2.43 \times 10^{7} \mathrm{Cfu} / \mathrm{g}$, $2.69 \times 10^{7} \mathrm{Cfu} / \mathrm{g}$ for the zero hour, 14th, 28th, 48th, 52nd and 70th day respectively (Fig. 1). The total heterotrophic bacterial count in the control experiment ranged between $5.6 \times 10^{5} \mathrm{Cfu} / \mathrm{g}$ to $6.20 \times 10^{5} \mathrm{Cfu} / \mathrm{g}$. In both cases the growth of the heterotrophic bacterial organisms was lowest at zero hour and highest on the 70th day. There was significant difference at $\mathrm{p}<0.05$ level for water hyacinth powder treated polluted soil and the unamended control $(\mathrm{F}[2,15]=2.277)$.

In addition, the total culturable heterotrophic fungal count at baseline was $4.8 \times 10^{5} \mathrm{Cfu} / \mathrm{g}$. This increased from $5.3 \times 10^{5} \mathrm{Cfu} / \mathrm{g}$ to $2.5 \times 10^{7} \mathrm{Cfu} / \mathrm{g}$ and $4.3 \times 10^{5} \mathrm{Cfu} / \mathrm{g}$ to $6.2 \times 10^{5} \mathrm{Cfu} / \mathrm{g}$ for water hyacinth recipe/nutrient powder option and control experiments respectively (Fig. 2). 


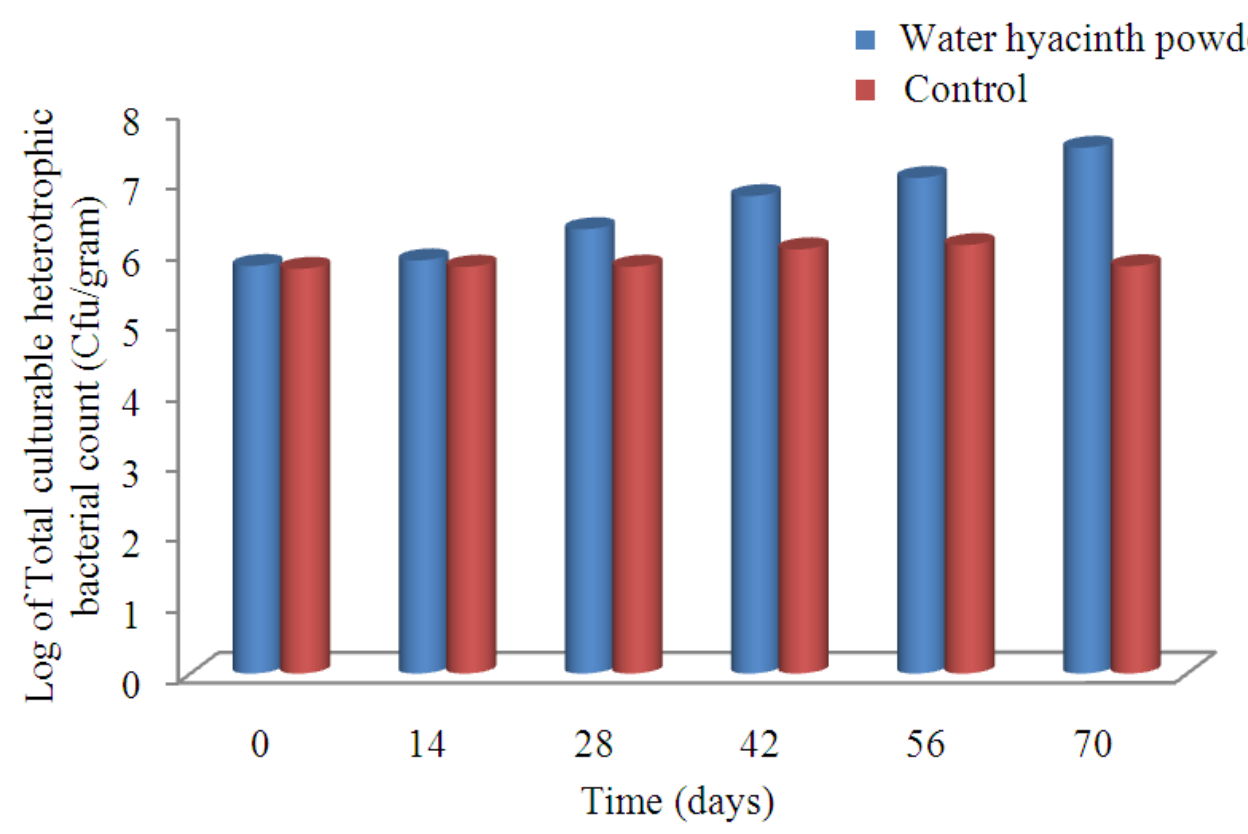

Fig. 1. Changes in total culturable heterotrophic bacterial counts in the water hyacinth powder treated polluted soil and control during the 70 th day study

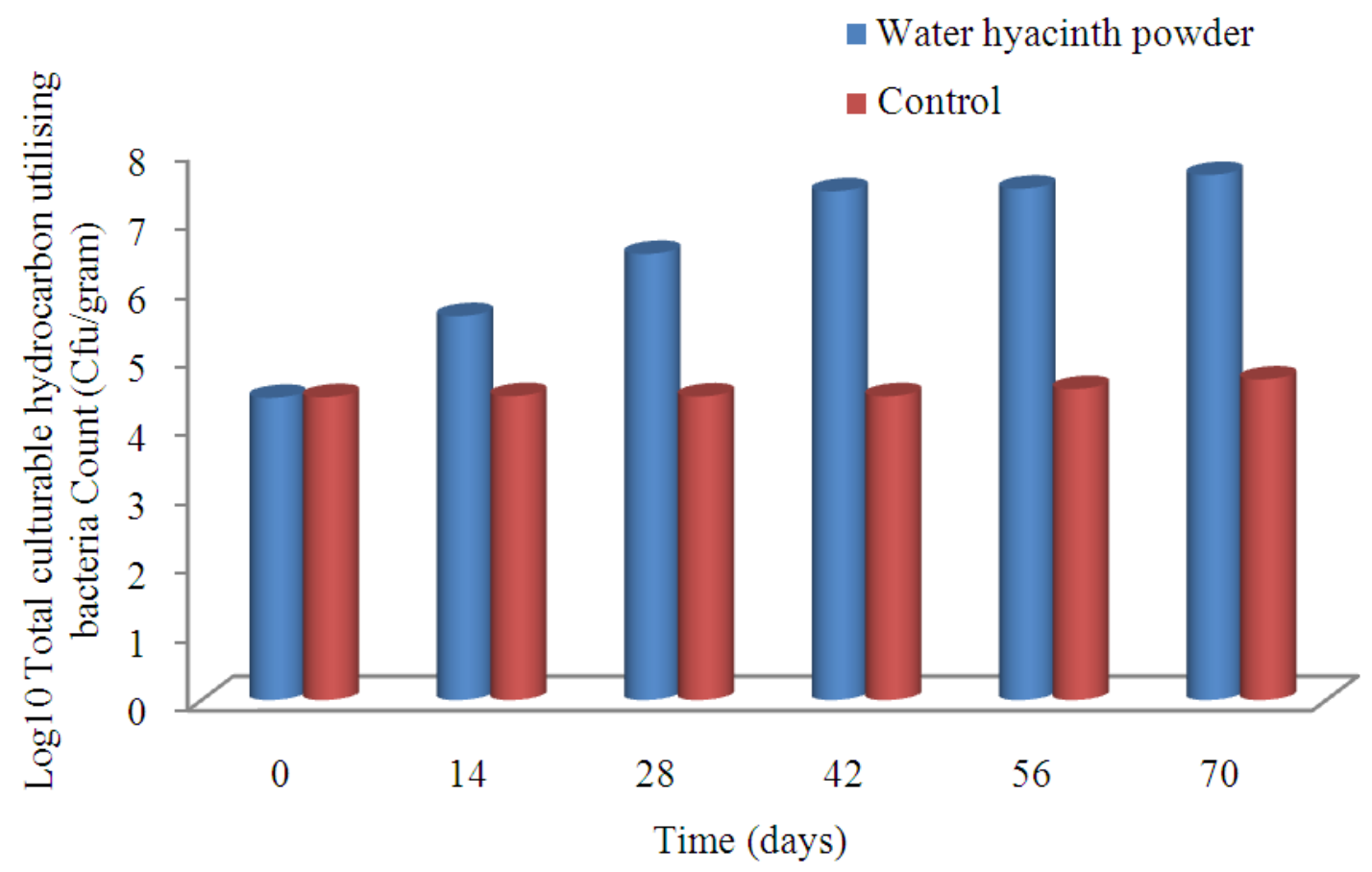

Fig. 2. Changes in total culturable heterotrophic fungal counts in the water hyacinth powder treated polluted soil and control during the 70 th day study 


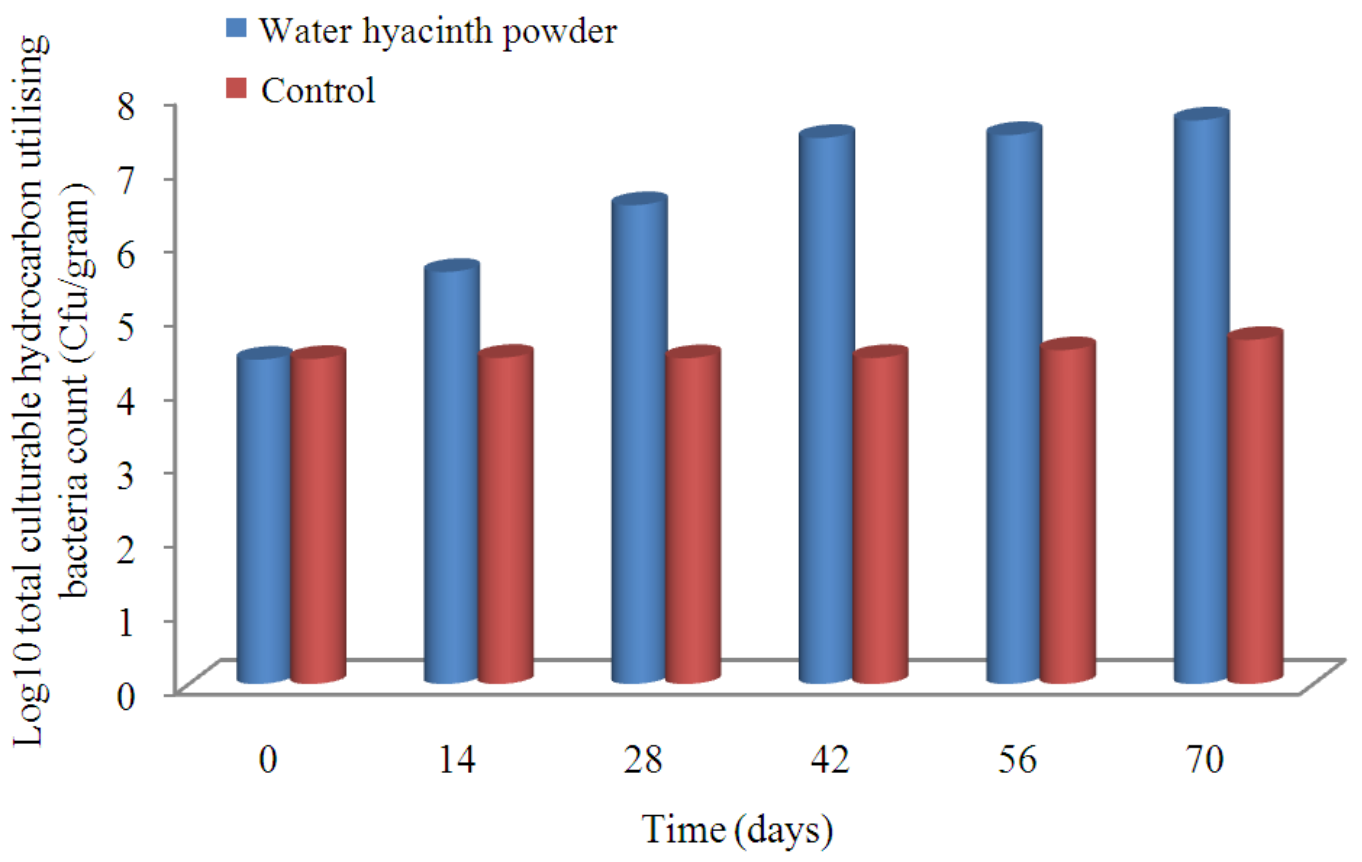

Fig. 3. Changes in total culturable hydrocarbon utilizing bacterial counts in the water hyacinth powder treated polluted soil and control

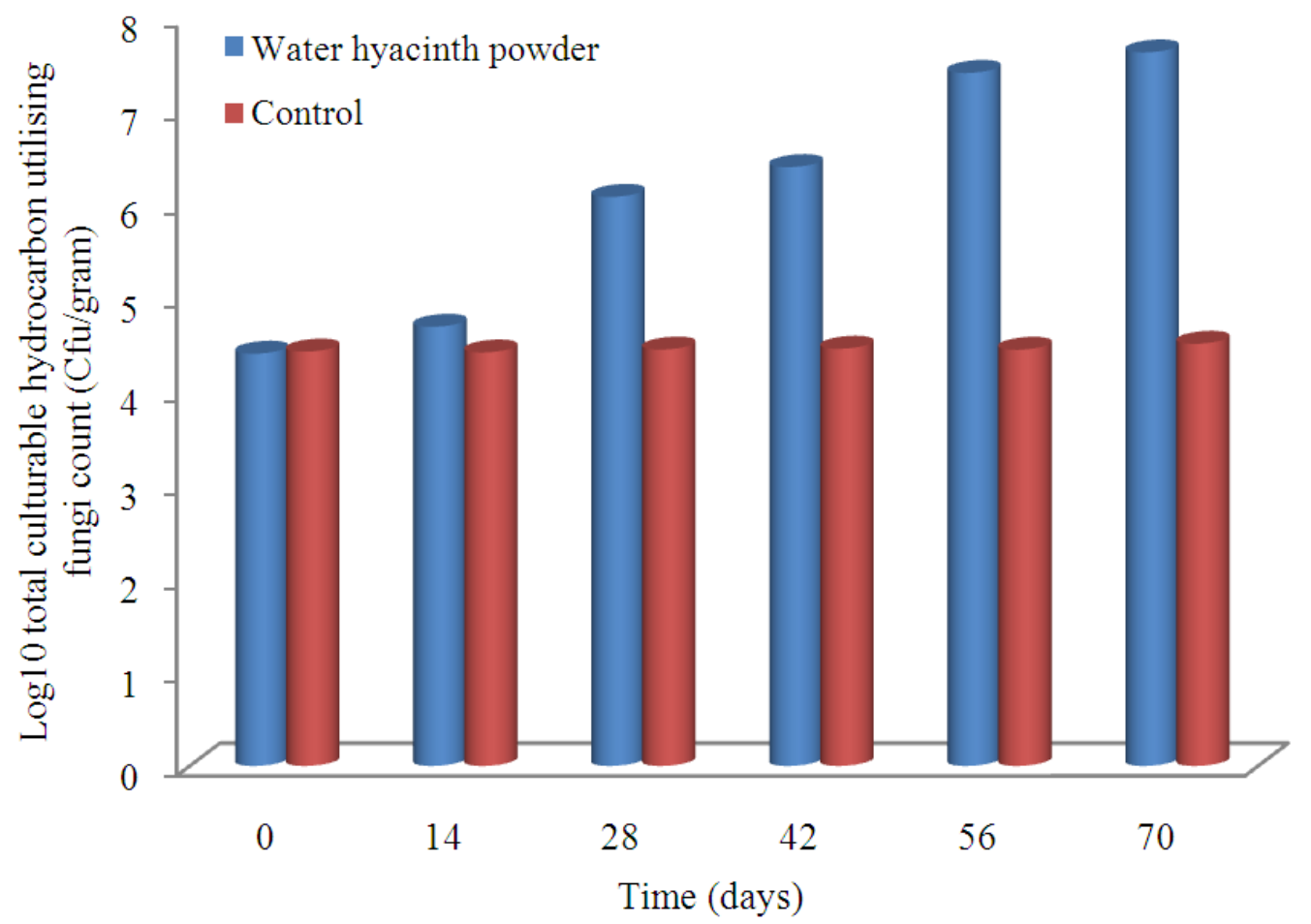

Fig. 4. Changes in the total culturable hydrocarbon utilizing fungi count of the Water hyacinth powder treated option and control 
Statistical analyses have shown that there was significant difference at $\mathrm{p}<0.05$ level for the two conditions (water hyacinth and control).

The hydrocarbon utilizing bacterial species responded to the nutrient amendment with water hyacinth recipe. The total culturable hydrocarbon utilizing bacterial count in water hyacinth expect increased at zero hour from $2.5 \times 10^{4} \mathrm{Cfu} / \mathrm{g}$ to $3.7 \times 10^{7}$ $\mathrm{Cfu} / \mathrm{g}$ during the period of study that lasted for seventy (70) days. The total culturable hydrocarbon utilizing bacterial counts in the control experiment ranged from $2.5 \times 10^{4} \mathrm{Cfu} / \mathrm{g}$ at zero hour to $1.68 \times 10^{5} \mathrm{Cfu} / \mathrm{g}$ at 70 th day of the study (Fig. 3). Post HOC comparisons using the tukey HSD test indicated that the mean score for control $(\mathrm{m}=4.7259, \mathrm{SD}=0.48758)$ differed significantly from both the mean scores of water hyacinth recipe and control experimental groups.

In the Water hyacinth nutrient powder amended option experiment, the total culturable hydrocarbon utilizing fungal counts ranged were $2.5 \times 10^{4} \mathrm{Cfu} / \mathrm{g}$, $2.03 \times 10^{3} \mathrm{Cfu} / \mathrm{g}, \quad 1.20 \times 10^{6} \mathrm{Cfu} / \mathrm{g}, 2.49 \times 10^{6} \mathrm{Cfu} / \mathrm{g}$, $2.68 \times 10^{7} \mathrm{Cfu} / \mathrm{g}$ at zero hour, 14th 28 th $48 \mathrm{th}, 56$ th and 70 th day of the experiment respectively.

The un-amended control experiment had its culturable hydrocarbon utilising fungi count increased from $2.6 \times 10^{4}$ to $1.81 \times 10^{5} \mathrm{Cfu} / \mathrm{g}$ (Fig. 4). The amounts of limiting nutrients such as nitrogen and phosphorus present in this polluted soil were very low. This called for the amendment of the polluted mangrove soil with water hyacinth nutrient powder. Managing water hyacinth which is a problematic plant species in the Nigerian water ways by putting it into effective use such as in bioremediation will definitely be a welcome development in Sub-Saharan Africa and other parts of the world where the plant posses' ecological problems and cheaper remediation technologies are regularly sought for.

Table 2. Baseline physico-chemical and microbiological properties of petroleum hydrocarbon-impacted mangrove soil in the Niger Delta

\begin{tabular}{ll}
\hline Parameters & Values \pm S.D \\
\hline $\mathrm{pH}$ & $7.5 \pm 0.04$ \\
Conductivity $(\mu \mathrm{s} / \mathrm{cm})$ & $2380 \pm 3.12$ \\
Nitrate $\left(\mathrm{NO}_{3}^{-}\right)(\mathrm{mg} / \mathrm{kg})$ & $10.52 \pm 0.286$ \\
Phosphate $\left(\mathrm{PO}_{4}^{-}\right)(\mathrm{mg} / \mathrm{kg})$ & $8.11 \pm 0.021$ \\
Total organic carbon $(\%)$ & $3.30 \pm 0.00$ \\
Total petroleum hydrocarbon $(\mathrm{mg} / \mathrm{kg})$ & $12934.75 \pm 0.00$ \\
Total hydrocarbon $(\mathrm{mg} / \mathrm{kg})$ & $14102.22 \pm 0.127$ \\
Total culturable heterotrophic bacterial count $(\mathrm{Cfu} / \mathrm{g})$ & $6.1 \times 10^{5} \pm 0.004$ \\
Total culturable heterotrophic fungal count $(\mathrm{Cfu} / \mathrm{g})$ & $4.8 \times 10^{5} \pm 0.111$ \\
Total culturable hydrocarbon utilizing bacterial count $(\mathrm{Cfu} / \mathrm{g})$ & $3.5 \times 10^{4} \pm 0.025$ \\
Total culturable hydrocarbon utilizing fungal count $(\mathrm{Cfu} / \mathrm{g})$ & $2.6 \times 0^{4} \pm 0.024$ \\
\hline
\end{tabular}

$\mathrm{Cfu} / \mathrm{g}$; colony forming unit per gram, $\mu \mathrm{s} / \mathrm{cm}$; microsiemmens per centimetre, S.D; Standard deviation

\begin{tabular}{|c|c|c|c|c|c|c|c|c|c|c|c|c|c|c|c|}
\hline \multirow[b]{2}{*}{ Isolate no } & \multicolumn{5}{|c|}{$\begin{array}{l}\text { Morpholoy } \\
\text { and Gram } \backslash\end{array}$} & \multirow{2}{*}{$\begin{array}{l}\text { Methyl } \\
\text { Red }\end{array}$} & \multirow{2}{*}{$\begin{array}{l}\text { Voges } \\
\text { Proskauer }\end{array}$} & \multirow{2}{*}{$\begin{array}{l}\text { Starch } \\
\text { Hydrolysis }\end{array}$} & \multirow{2}{*}{$\begin{array}{l}\mathrm{H}_{2} \mathrm{~S} \\
\text { Productio }\end{array}$} & \multirow[b]{2}{*}{ n Oxidase } & \multirow[b]{2}{*}{ e Glucose } & \multirow[b]{2}{*}{ Lactose } & \multirow[b]{2}{*}{ Mannitol } & \multirow[b]{2}{*}{ Sucrose } & \multirow{2}{*}{$\begin{array}{l}\text { Identities } \\
\mathrm{f} \text { the bacterial } \\
\text { isolates }\end{array}$} \\
\hline & Reaction & Motility & Citrate & e Catalase & Indole & & & & & & & & & & \\
\hline $\mathrm{HUB}_{1}$ & Rods - & + & + & + & - & - & - & - & - & + & + & + & + & + & Pseudomonas species \\
\hline $\mathrm{HUB}_{2}$ & Rods - & + & + & + & - & + & - & + & + & - & $+\mathrm{G}$ & + & + & + & Citrobacter species \\
\hline $\mathrm{HUB}_{3}$ & Rods + & + & + & + & - & + & + & + & - & - & + & + & + & - & Bacillus species \\
\hline $\mathrm{HUB}_{4}$ & Rods + & + & + & + & - & + & + & + & - & - & + & + & + & - & Bacillus species \\
\hline $\mathrm{HUB}_{6}$ & Rods - & + & + & + & - & + & - & + & + & - & $+\mathrm{G}$ & + & + & + & Citrobacter species \\
\hline $\mathrm{HUB}_{7}$ & Cocci + & - & - & - & - & + & - & - & - & + & + & + & + & + & Micrococcus species \\
\hline $\mathrm{HUB}_{8}$ & Rods - & + & + & + & + & + & + & + & - & + & + & - & + & + & Vibrio species \\
\hline $\mathrm{HUB}_{9}$ & Rods + & - & - & + & - & - & + & - & - & - & - & - & - & + & Corynebacterium species \\
\hline $\mathrm{HUB}_{10}$ & Cocci + & + & - & + & - & + & - & - & - & + & + & + & + & + & Micrococcus species \\
\hline $\mathrm{HUB}_{11}$ & Rods - & - & + & + & - & + & - & - & + & + & + & - & - & + & Flavobacterium species \\
\hline $\mathrm{HUB}_{13}$ & Rods - & - & + & + & - & + & - & - & + & + & + & - & - & + & Flavobacterium species \\
\hline $\mathrm{HUB}_{14}$ & Cocci+ & - & - & + & - & + & - & - & - & + & + & + & + & + & Micrococcus species \\
\hline $\mathrm{HUB}_{15}$ & Rods + & - & - & + & - & - & + & - & - & - & - & - & - & + & Corynebacterium species \\
\hline
\end{tabular}

+ G-Positive with gas production positive, -; negative and +; positive 
The slight increase observed in the heterotrophic/hydrocarbon utilising bacterial, fungi counts in the control experiment from the zero day to the 70 th day is as a result of the fact that it is not amended with nutrient. Again, the little nutrients (nitrate and phosphate) available and present are likely not available to the microorganisms. The response of indigenous hydrocarbon utilizing bacteria to the bioremediation treatment was generally positive with higher population occurring progressively as time elapsed. The bacterial and fungal species exhibited ability to either degrade or utilize the different petroleum hydrocarbon components as sole carbon sources. Similarly, (Odokuma and Dickson, 2003) in a bioremediation study in a mangrove swamp in new Calabar River, Rivers State was able to scale-up the hydrocarbon-utilizing bacteria using NPK fertilizer. The NPK fertilizer increased the bioload of the polluted mangrove soil from $1.5 \times 103$ to $1.5 \times 10^{9} \mathrm{Cfu} / \mathrm{g}$. In addition, in another study in a contaminated sandyloamy soil in the Port Harcourt, Okolo et al. (2005) documented the use of poultry manure to increase the hydrocarbon utilizing bacteria count significantly. The hydrocarbon utilizing bacterial isolates obtained from this study included Pseudomonas species, Bacillus species, Citrobacter species, Micrococcus species, Vibrio species, Flavobacterium species and Corynebacterium (Table 3 ).

Table 4. Identities of the hydrocarbon utilizing fungal isolates in the water hyacinth nutrient powder treated polluted soil

\begin{tabular}{|c|c|c|c|}
\hline Isolate & Culture characteristics & Microscopic characteristics & Fungal identity \\
\hline$\overline{\mathrm{HUF}_{1}}$ & $\begin{array}{l}\text { Pure white, with abundant } \\
\text { cottonymycelium and white reverse }\end{array}$ & $\begin{array}{l}\text { sporangiophores, rhizoid, } \\
\text { Spongisphore Non-septate and black } \\
\text { sporangium containing }\end{array}$ & $\begin{array}{l}\text { Rhizopus spp. } \\
\text { hemispherical }\end{array}$ \\
\hline collumela & & & \\
\hline $\mathrm{HUF}_{2}$ & $\begin{array}{l}\text { Powdery, dark brown, flatty spread } \\
\text { on the surface of the solid } \\
\text { medium with brown reverse. }\end{array}$ & $\begin{array}{l}\text { Septate and branched hyphae } \\
\text { with conidia in chains }\end{array}$ & Aspergillus spp. \\
\hline $\mathrm{HUF}_{3}$ & $\begin{array}{l}\text { Whitish and cottony mycelium } \\
\text { with pinkish pigments at the centre, } \\
\text { and reverse side was brown }\end{array}$ & $\begin{array}{l}\text { Segmented canoe-shaped spores } \\
\text { and branched Conidiophores. }\end{array}$ & Fusarium spp. \\
\hline $\mathrm{HUF}_{4}$ & Surface was first greyish white and woolly, & $\begin{array}{l}\text { Dark septate mycelium with } \\
\text { short conidiophores. Conidia were } \\
\text { large with longitudinal septations }\end{array}$ & Alternaria spp. \\
\hline $\mathrm{HUF}_{5}$ & $\begin{array}{l}\text { Powdery, dark brown, flaty spread } \\
\text { on the surface of the solid } \\
\text { medium with brownish reverse }\end{array}$ & $\begin{array}{l}\text { Septate and branched } \\
\text { hyphae and conida in chains }\end{array}$ & Aspergillus spp. \\
\hline $\mathrm{HUF}_{6}$ & $\begin{array}{l}\text { Grey colonies that were } \\
\text { largeWith white border. } \\
\text { Reverse was white }\end{array}$ & $\begin{array}{l}\text { Long conidiophores consisting } \\
\text { of broom like conida in chains }\end{array}$ & Penicillium spp. \\
\hline $\mathrm{HUF}_{7}$ & $\begin{array}{l}\text { Yeast-like colony, soft and } \\
\text { smooth. Pinkish in colour } \\
\text { and turned red as it was old }\end{array}$ & $\begin{array}{l}\text { Oval shaped budding cells } \\
\text { with few rudimentary pseudohyphae. } \\
\text { No ascospores present. }\end{array}$ & Rhodotorula spp. \\
\hline $\mathrm{HUF}_{8}$ & Whitish and cottony & $\begin{array}{l}\text { Segmented canoe-like spores, } \\
\text { with branched and } \\
\text { segmented conidiophores }\end{array}$ & Fusarium spp. \\
\hline $\mathrm{HUF}_{9}$ & $\begin{array}{l}\text { Yellow green dense mycelia. } \\
\text { Powdery and light yellow reverse }\end{array}$ & $\begin{array}{l}\text { Long conidiophores consisting } \\
\text { of broom like conidia in Chains }\end{array}$ & Penicillium spp. \\
\hline $\mathrm{HUF}_{10}$ & $\begin{array}{l}\text { White colony mycelium which } \\
\text { developed within } 4 \text { days } \\
\text { with extensive sub-surface }\end{array}$ & $\begin{array}{l}\text { Coarse hyphae that segment } \\
\text { into rectangular arthrospores varying in sizes }\end{array}$ & Geotrichium spp. \\
\hline $\mathrm{HUF}_{11}$ & White and cottony mycelium & $\begin{array}{l}\text { Multi-segmented canoe-like } \\
\text { spores with branched and } \\
\text { segmented conidiophores }\end{array}$ & Fusarium spp. \\
\hline $\mathrm{HUF}_{12}$ & $\begin{array}{l}\text { Creamy ovoid colonies which } \\
\text { were easily picked }\end{array}$ & $\begin{array}{l}\text { Spherical cells in clusters } \\
\text { with buds }\end{array}$ & Saccharomyces Sp. \\
\hline
\end{tabular}


Eziuzor and Okpokwasili (2009) studied bioremediation of crude oil polluted mangrove soil in Port Harcourt. They used NPK as source of limiting nutrient and reported the isolation of hydrocarbon utilizing bacteria such as Acinetobacter, Arthrobacter, Bacillus, Citrobacter, Alcaligenes, Flavobacteria, Pseudomonas, Vibrio and Corynebacterium. The hydrocarbon utilizing fungal organisms isolated from this study include the following: Penicillium, Mucor, Fusarium, Saccharomyces, Rhodotorula, Alternaria, Rhizopus, Geotrichium and Aspergillus (Table 4). In Nigeria, the fungi reported as oil degraders in aquatic environments in the petroleum producing areas by (Obire, 1988) were Aspergillus, Aureobasidium, Candida, Rhodosporodium, Cepthalosporium, Rhodotorula, Saccharomyces, Aspergillus niger, Aspergillus terreus, Blastomyces spp., Botryodioplodia, Fusarium spp., Nigrospora spp., Penicillium and Trichoderma harianum. The use of white-rot fungus, Lentinus subdunus for mycoremediation of engine oil polluted soil in western Nigeria has been reported (Adenipekun and Fasidi, 2005).

\subsection{Physico-Chemical Studies}

The $\mathrm{pH}$ of the polluted mangrove soil was slightly alkaline soil. In the water hyacinth powder amended soil, the $\mathrm{pH}$ for the zero hour and 70th day were 7.55, 7.54, $7.68,7.69$ and 7.49 respectively (Fig. 5). The $\mathrm{pH}$ of the control experiment was alkaline within the 70 days study, but in a static pattern (Fig. 5). Statistical analyses showed that there was statistical significance at the $\mathrm{p}<0.05$ for the two conditions $[\mathrm{f}(2,25)=8.969$, $\mathrm{p}<0.003]$. Post HOC comparisons test indicated that the mean score for the control $(\mathrm{M}=7.5250, \mathrm{SD}=0.04637)$ differed significantly from the mean score for the Water hyacinth treated option $(\mathrm{m}=7.7167, \mathrm{~S} . \mathrm{D}=0.074)$ at $95 \%$ confidence interval. In addition, from composite analyses, the $\mathrm{pH}$ value of water hyacinth organic fertilizer/powder was $9.91 \pm 0.027$ respectively (Table 5). It is worthy to mention that the $\mathrm{pH}$ values recorded in the water hyacinth powder experiment did not follow a consistent pattern/trend. This $\mathrm{pH}$ fluctuation may be as a result of production of metabolites at different stages/period of the bioremediation.

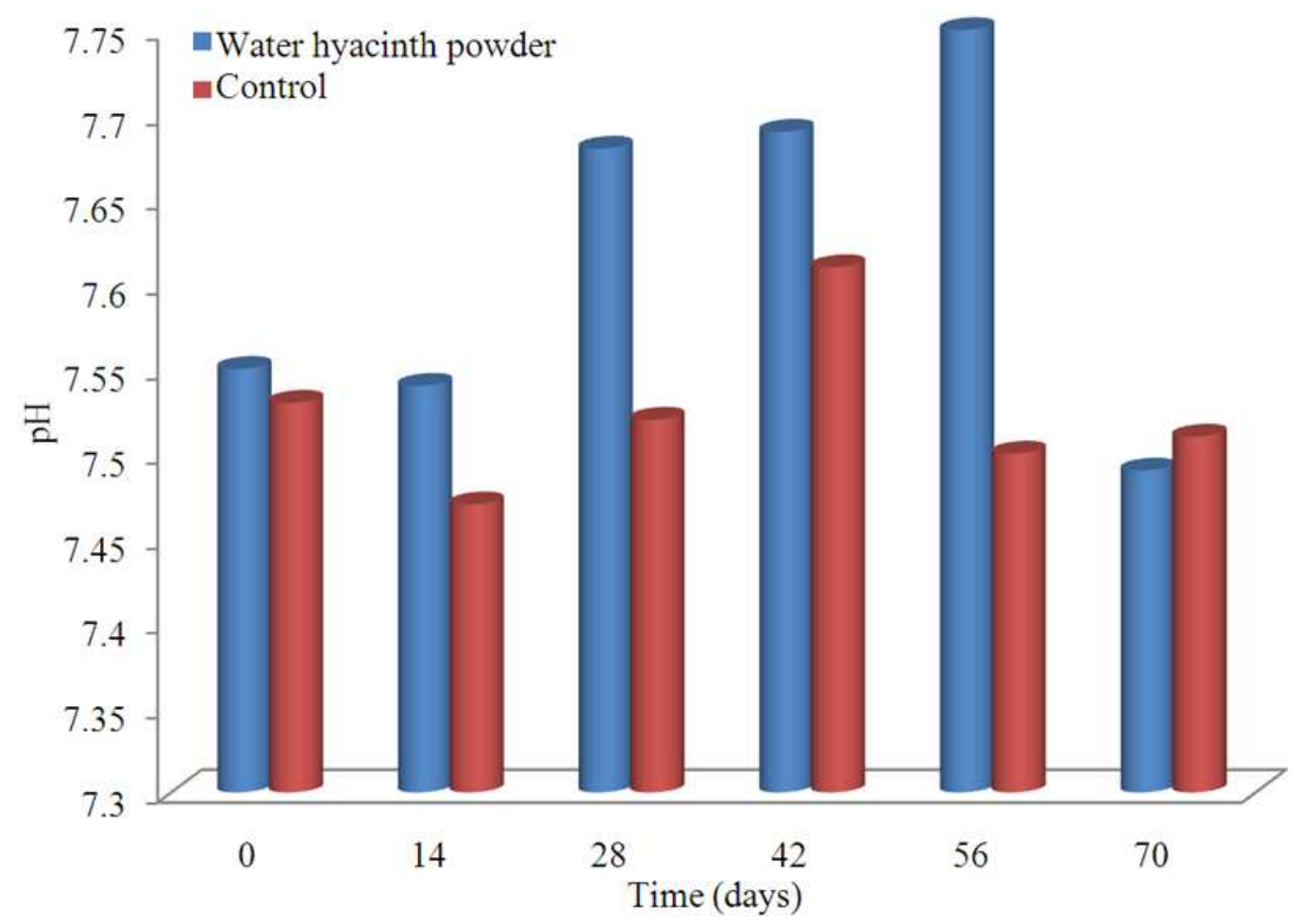

Fig. 5. Changes in the $\mathrm{pH}$ of the Water hyacinth powder treated option and control during the 70day study 


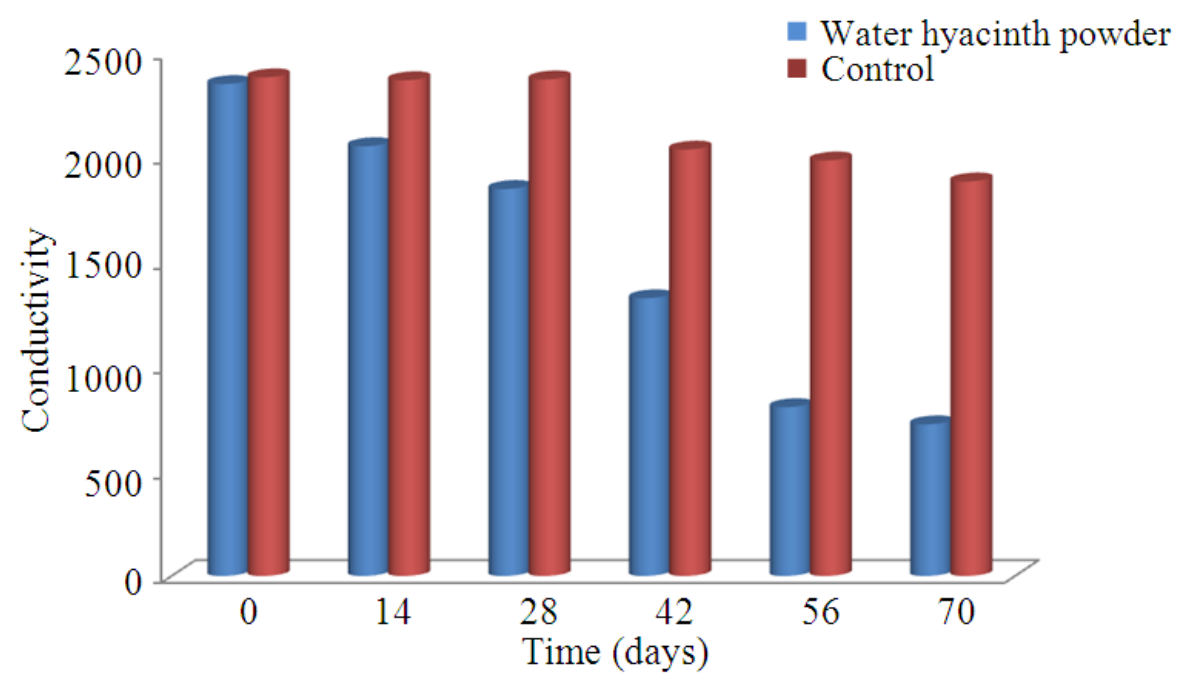

Fig. 6. Changes in the conductivity $(\mu \mathrm{S} / \mathrm{cm})$ of the water hyacinth powder treated option and control during the 70 day study

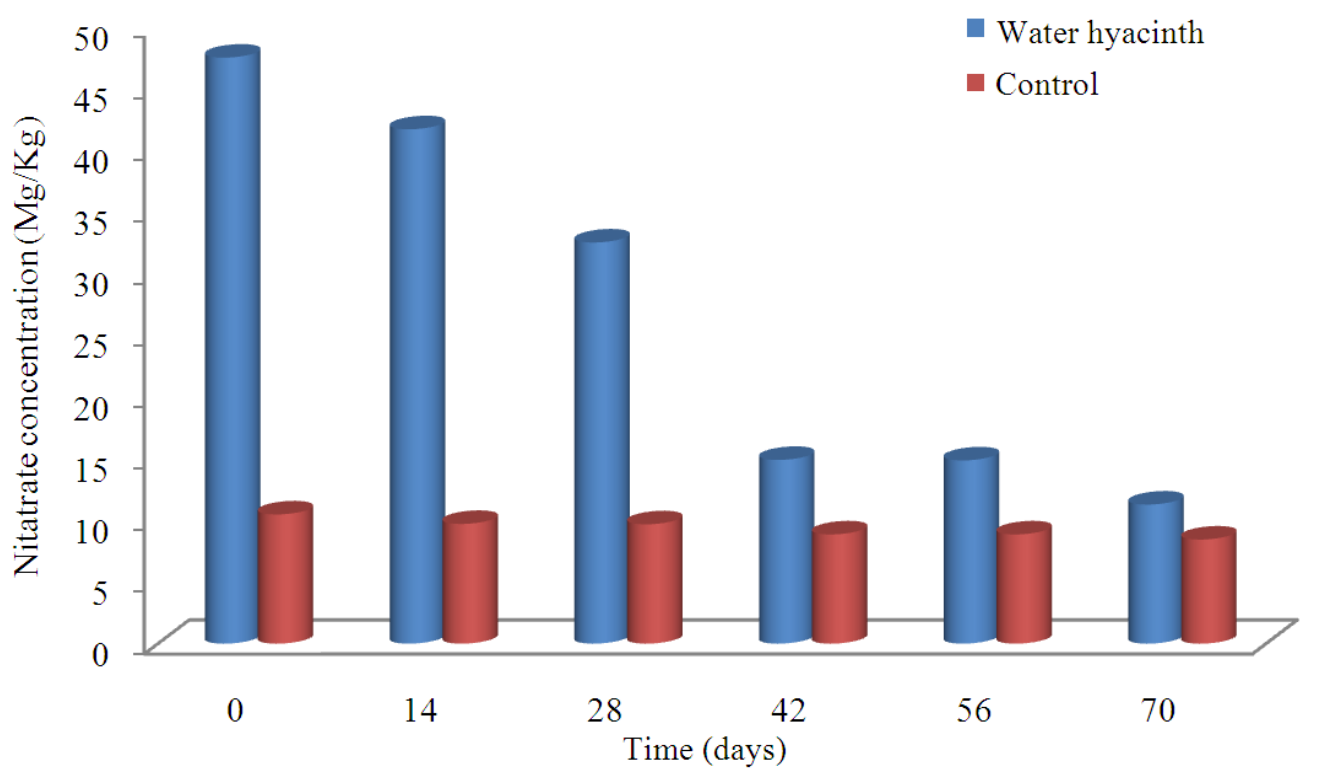

Fig. 7. Changes in the concentration of nitrate $(\mathrm{Mg} / \mathrm{Kg})$ of the Water hyacinth powder treated option and control during the $70 \mathrm{day}$

In the baseline study of the polluted mangrove soil, the conductivity level was $2380 \mu \mathrm{sm}^{-1}$. This high value shows that the environment is salt water mangrove or brackish water mangrove. But observation at the environment shows fluctuation of the salty taste of mangrove water within two tides of the day. This fluctuation is an indication that the mangrove of study is a brackish water mangrove. In the water hyacinth recipe amended polluted soil, conductivity decreased from 2399 $\mu \mathrm{s} \mathrm{cm}^{-1}$ to $724 \mu \mathrm{s} \mathrm{cm}^{-1}$ during the 70 days study. In addition, control experimental set-up showed very slight decrease in conductivity from $2381-1884 \mu \mathrm{sm}^{-1}$ (Fig. 6). There was significant difference in the two (2) conditions $[\mathrm{f}(2,15)=0.289, \mathrm{p}=0.753)$ at $95 \%$ confidence interval. The conductivity value of the water hyacinth recipe from composite analyses was $89.47 \mu \mathrm{s} / \mathrm{cm} \pm 5.110$ (Table 5). This high conductivity value is because the life water hyacinth was plucked from marine environment. 


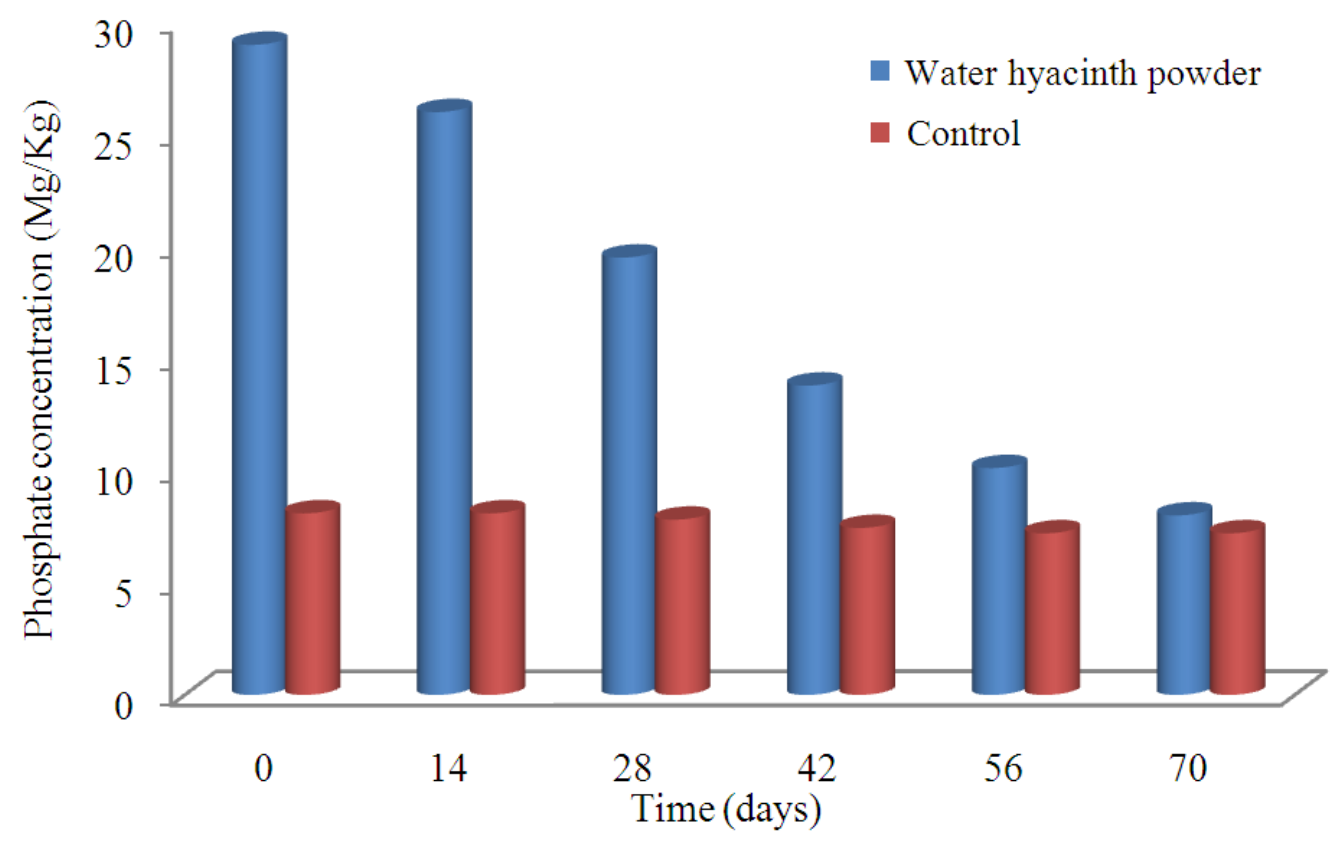

Fig. 8. Changes in the concentration of phosphate $(\mathrm{Mg} / \mathrm{Kg})$ in the polluted soil amended with water hyacinth powder and control during the 70day study

Table 5. Chemical composition of the water hyacinth recipe organic fertilizer used in the study

\begin{tabular}{lr}
\hline Parameters & \multicolumn{1}{c}{ Values \pm S.D } \\
\hline pH & $9.91 \pm 0.027$ \\
Conductivity $\left(\mu \mathrm{s} \mathrm{cm}^{-1}\right)$ & $89.47 \pm 5.100$ \\
Nitrate $\left(\mathrm{Mg} \mathrm{kg}^{-1}\right)$ & $38.48 \pm 0.050$ \\
Phosphate $\left(\mathrm{Mg} \mathrm{kg}^{-1}\right)$ & $27.89 \pm 0.018$ \\
\hline
\end{tabular}

Real values are mean of triplicate analyses, S.D: Standard deviation

Conductivity study in bioremediation experiments both in-situ and ex-situ is related to salinity but it is often used than salinity as a result of ease of measurement (Zhu et al., 2001). This observation of decrease in conductivity could be as a result of the facts that the salts present in the polluted mangrove soil may have been utilised as micro-nutrients by microorganisms. Invariably, it means that the exchange ions in the polluted mangrove soils were used by the hydrocarbon utilizers for increase in biomass. As the salts are used as micronutrients, this eventually lead to reduction of conductivity.

$\mathrm{Abu}$ and Akomah (2008) similarly reported a decrease in the conductivity of a treated wetland undergoing bioremediation under laboratory simulation. They cited uptake of exchange ions by microorganisms as the major reason for such decrease.
There was a decrease in the level of nitrate in water hyacinth recipe amended polluted soil as it decreased from $47.52 \mathrm{mg} \mathrm{kg}^{-1}$ to 11.28 within the 70 days study period (Fig. 7). In the control experiment, there was slight decrease in nitrate concentration from $10.48 \mathrm{mg} \mathrm{kg}^{-1}$ to $8.44 \mathrm{mg} \mathrm{kg}^{-1}$ (Fig. 7). There was significant difference for the two experimental conditions $[f(2,14)=5.654$, $\mathrm{p}<0.015]$. The nitrate concentration in the water hyacinth fertilizer was $38.48 \mathrm{mg} \mathrm{kg}^{-1}$ (Table 5). This showed that the powder from water hyacinth is nitrate rich.

The concentration of phosphate in the water hyacinth fertilizer was $27.89 \mathrm{mg} \mathrm{kg}^{-1}$ (Table 5). This also showed that the water hyacinth powder is rich in phosphate. The concentration of phosphate immediately after amendment increased to $29.01 \mathrm{mg} \mathrm{kg}^{-1}$ in the water hyacinth amended option (Fig. 8). The amount of phosphate decreased in the water hyacinth recipe amended option from $29.01 \mathrm{mg} \mathrm{kg}$ to $8.01 \mathrm{mg} \mathrm{kg}^{-1}$ during the 70 days study. The control experiment showed slight decrease at $8.10 \mathrm{mg} \mathrm{kg}^{-1}$ at zero hours to $7.21 \mathrm{mg} \mathrm{kg}^{-1}$. There was significant difference at $\mathrm{p}<0.05$ level for the two conditions [ $\mathrm{f}(2,15)=4.922$, $\mathrm{p}<0.023]$. The phosphate and nitrate concentrations in the treated option decreased downwards in specific pattern from the 28th day to the 70th day. This is an indication that the limiting nutrients (Phosphate and nitrate) were used by microorganisms during the duration of study. 
Frank Anayo Orji et al. / American Journal of Environmental Science 9 (4): 348-366, 2013

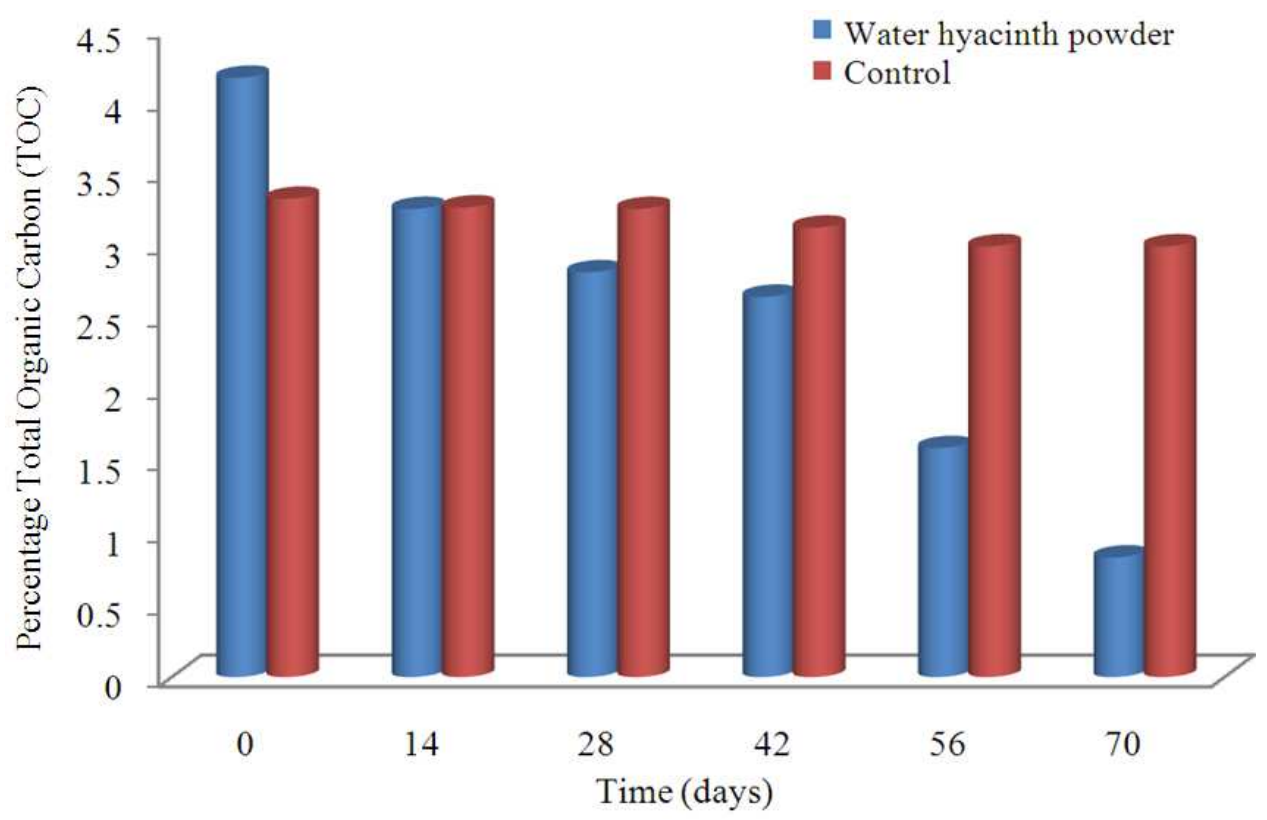

Fig. 9. Changes in the percentage Total Organic Carbon (\%TOC) in the polluted soil amended with water hyacinth powder and control during the 70day bioremediation study

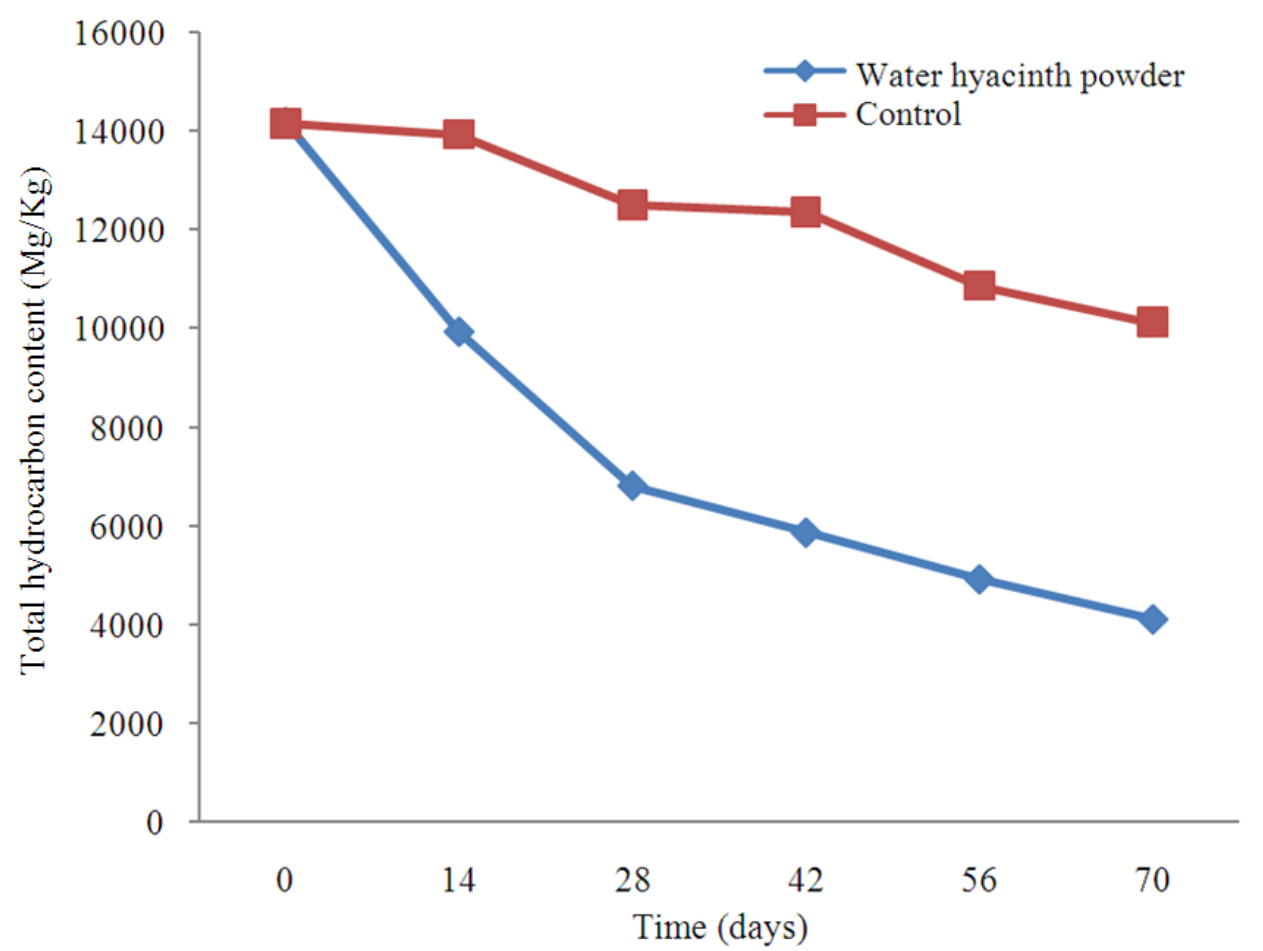

Fig. 10. Changes in the Total Hydrocarbon Content $(\mathrm{Mg} / \mathrm{Kg})$ in the polluted soil amended with Water hyacinth powder and control during the 70 day bioremediation study 
Adjustment of carbon/nitrogen/phosphorus ratios by the addition of nitrogen and phosphorus in the form of oleophilic fertilizers including paraffinized urea have been shown to stimulate microbial organisms into utilization of crude oil in different ecosystems, (Atlas and Bartha, 1972).

It has been well established that the availability of nitrogen and phosphorus limits the microbial degradation of hydrocarbon (Abu and Ogiji, 1996; Zhu et al., 2001). However, the slight decrease in the control experiment (without amendment) indicated that there was no active bioremediation in the control since it was not amended with nutrients.

Furthermore, amendment of the polluted mangrove soil with water hyacinth fertilizer increased the percentage Total Organic Carbon (\%TOC) at zero hour to $4.16 \%$. The $\%$ TOC decreased during the 70 day study decreased from 4.16 to $0.83 \%$ in water hyacinth amended option. The control experiment showed little decrease from 3.32 to $2.99 \%$ within the 70 days period of study (Fig. 9). There was no significant different observed within the two conditions (treatment and control $)[F(2,15)=0.631, p=0.545]$.
The Total Hydrocarbon (THC) in the water hyacinth recipe amended crude-oil polluted mangrove soil, decreased from $14187.03 \mathrm{mg} \mathrm{kg}^{-1}$ to $4119.52 \mathrm{mg} \mathrm{kg}^{-1}$ (Fig. 10). In the control experiment, the Total Hydrocarbon Content (THC) decreased at zero hour from $14146.19 \mathrm{mg} \mathrm{kg}^{-1}$ to $10114.29 \mathrm{mg} \mathrm{kg}^{-1}$ at the 70 th day of the study (Fig. 10). There was significant difference at the $\mathrm{p}<0.05$ level for the two conditions [ $\mathrm{f}$ $(2,15)=7.933, \mathrm{p}>0.007]$. Post HOC comparisms using tukey HSD test indicated that the mean score for the control $(\mathrm{m}=2645.50, \mathrm{SD}=1161.100)$ differed significantly from both the mean scores water hyacinth $(\mathrm{m}=7775.20, \mathrm{SD}=2258.238)$, with $\mathrm{p}<0.098$.

The changes in the concentration the Petroleum Hydrocarbon (TPH) was monitored at the zero hour/day, 28th day and 70th day of the study for each of treatments. In the water hyacinth recipe amended soil, Total Petroleum Hydrocarbon (TPH) reduced at zero hour from $12517.89 \mathrm{mg} \mathrm{kg}^{-1}$ to $3083.408 \mathrm{mg} \mathrm{kg}^{-1}$ at the 70th day (Fig. 11). In the control experiment, the total petroleum hydrocarbon decreased at zero hour from $12329.677 \mathrm{mg} \mathrm{kg}^{-1}$ to $10674.506 \mathrm{mg} \mathrm{kg}^{-1}$ (Fig. 11).

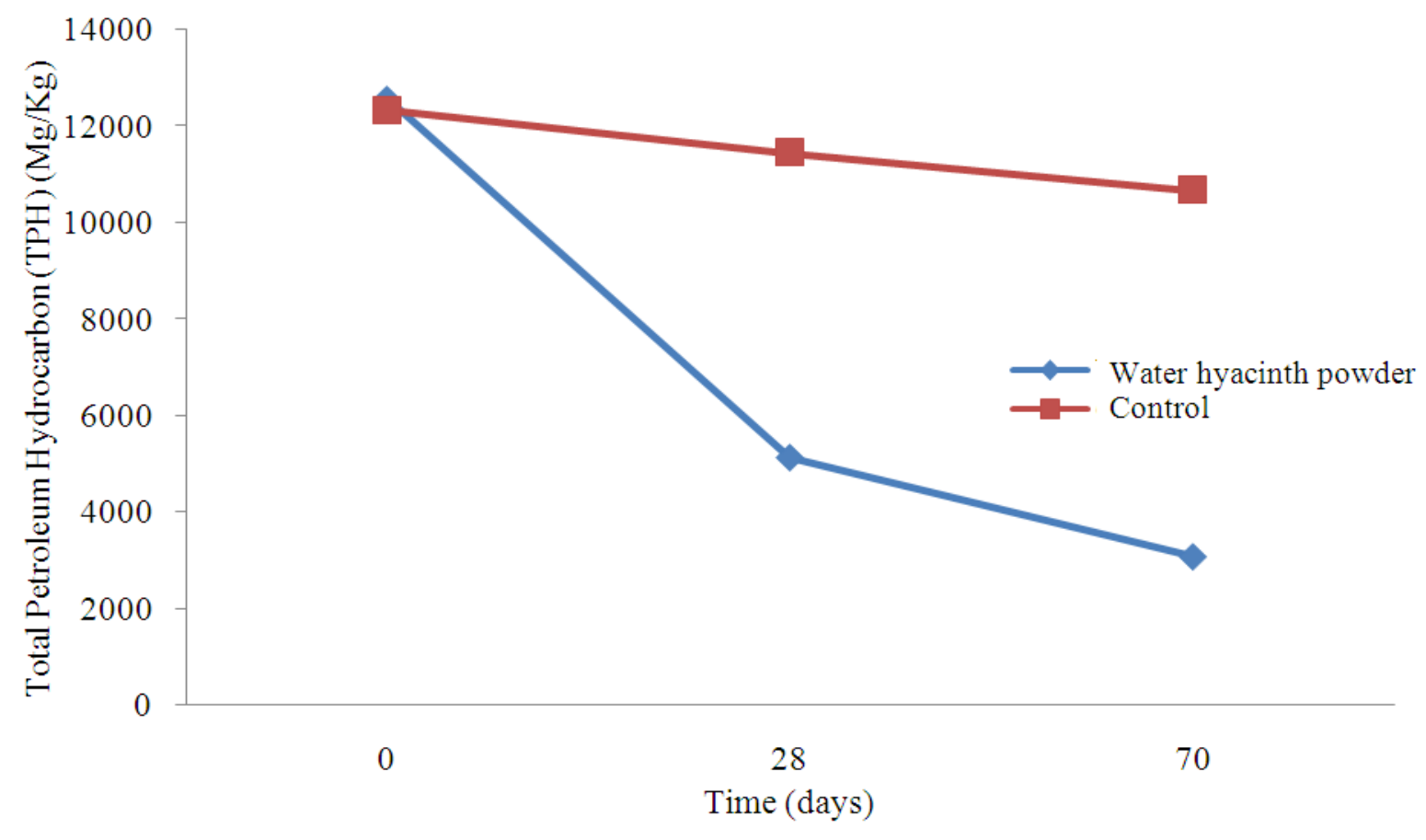

Fig. 11. Changes in the Total Petroleum Hydrocarbon $(\mathrm{Mg} / \mathrm{Kg})$ in the polluted soil amended with Water hyacinth powder and control during the 70 day bioremediation study 


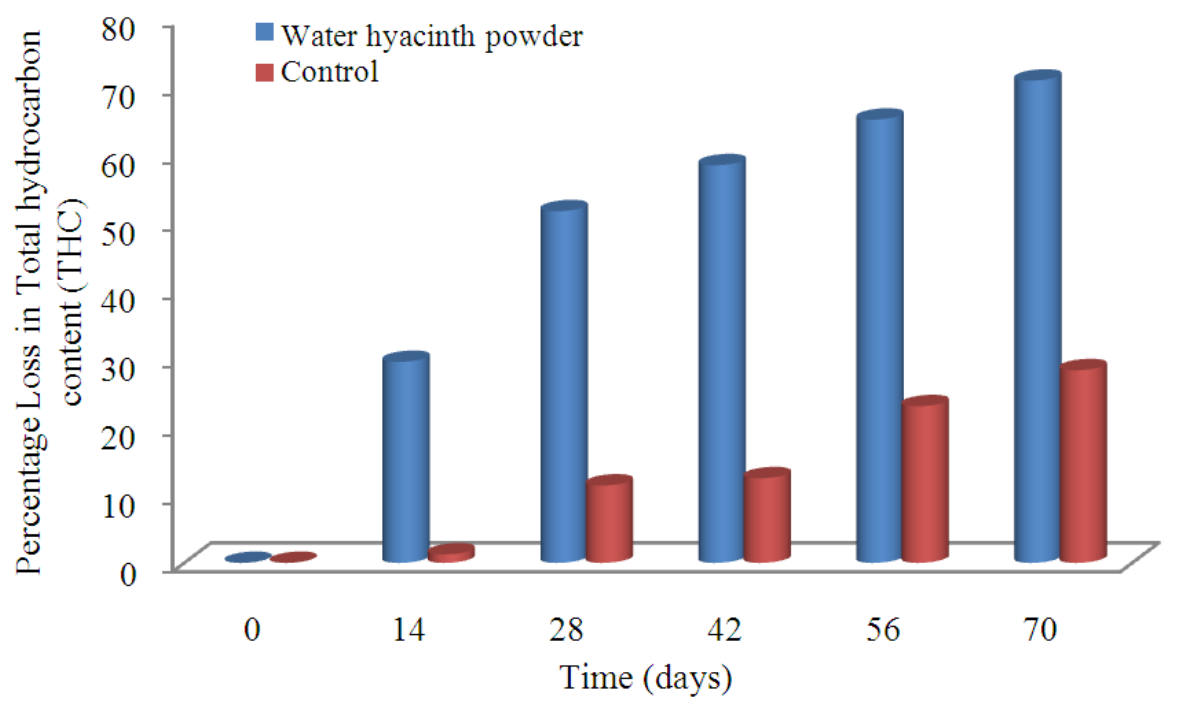

Fig. 12. Changes in the percentage loss of Total Petroleum Hydrocarbon $(\mathrm{Mg} / \mathrm{Kg})$ in the polluted soil amended with Water hyacinth powder and control during the 70 day bioremediation study

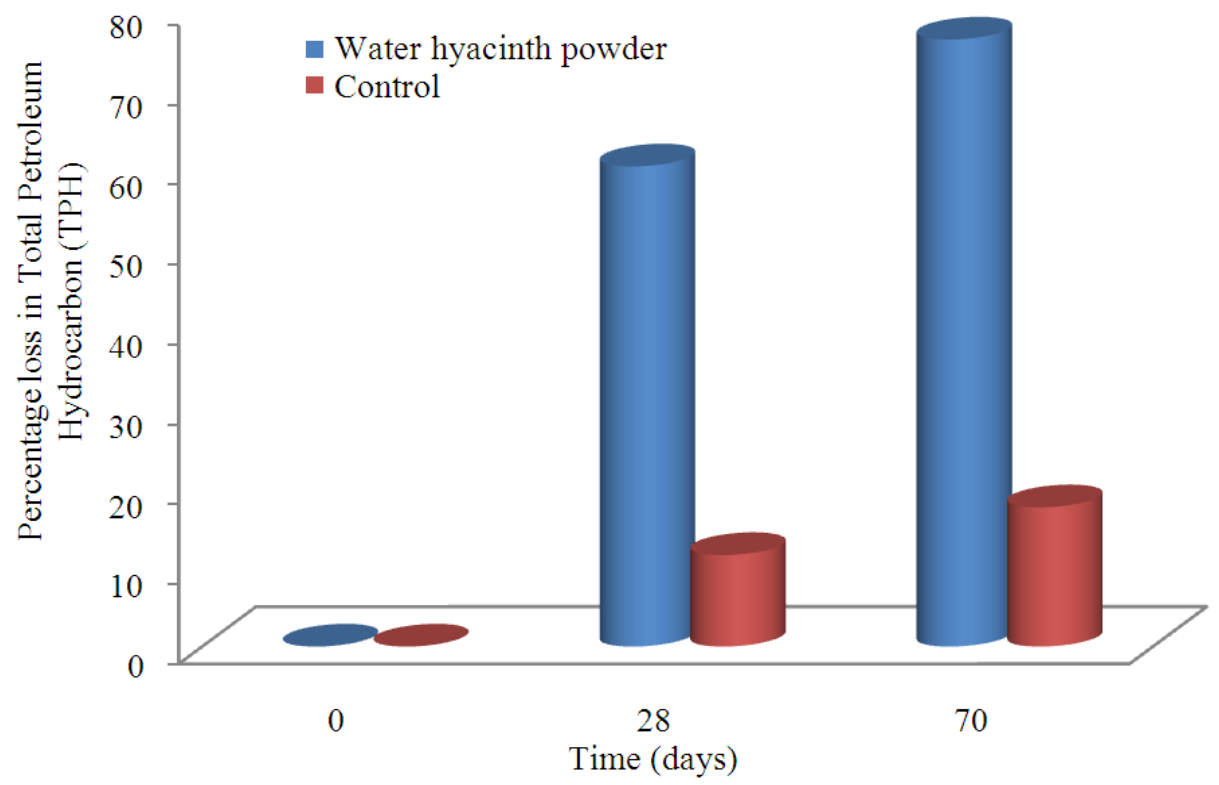

Fig. 13. Changes in the Percentage loss in Total Petroleum Hydrocarbon $(\mathrm{Mg} / \mathrm{Kg})$ in the polluted soil amended with Water hyacinth powder and control during the 70day bioremediation study

Post HOC comparisons using the tukey HSD test indicated that the mean scores of Total Petroleum Hydrocarbon $(\mathrm{TPH})$ for the control $(\mathrm{m}=1.2315 \mathrm{E} 4, \mathrm{SD}$ $=1608,14004$ ) differed significantly from the mean score for water hyacinth $(\mathrm{m}=7.6455 \mathrm{E} 3,3786.93565)$ with $\mathrm{p}<0.050$ at the $95 \%$ confidence level.
The percentage loss in Total Hydrocarbon Content (THC) on the zero day/hour was $0 \%$ for the two conditions. However, for Water hyacinth fertilizer experimental set-up, percentage Total Hydrocarbon Content (THC) lost were 29.50 to $70.78 \%$ between the 28th day to 70 th day respectively (Fig. 12). In the control 
experimental set-up, 1.25 to $28.28 \%$ of THC were lost between thw 28th day and 70th day of the study respectively (Fig. 12). There was significant difference at $\mathrm{p}<0.05$ level for the two conditions. Post Hoc comparisons using the Tukey HSD test indicated that the mean score for control at each point other than zero hour/day differed significantly from the means of water hyacinth $(\mathrm{p}<0.008)$. The percentage loss of Total Petroleum Hydocarbon (TPH) on the zero hour or day was $0 \%$ for all the two conditions (water hyacinth treatment option and the control). Futhermore on the 28th day of the bioremediatio study, 58.92 and $7.14 \%$ of TPH were lost in water hyacinth amended polluted soil and control experiment respectively (Fig. 13). On the 70 th day, 75.36 and $13.42 \%$ of TPH were lost in the water hyacinth recipe ammended soil and control experiments (Fig. 13). There was significant difference between the two conditions $(\mathrm{p}=0.50)$. Abu and Akomah (2008) studied laboratory assessment of anaerobic biodegradation in another Niger Delta wetland at Ebubu, Rivers State Nigeria. In a biostimulation laboratory model by (Abu and Akomah, 2008) using NPK fertilizer the total hydrocarbon at baseline $\left(1000 \mathrm{mg} \mathrm{kg}^{-1}\right)$ reduced to $600 \mathrm{mg} \mathrm{kg}^{-1}, 586 \mathrm{mg} \mathrm{kg}^{-1} 560 \mathrm{mg} \mathrm{kg}^{-1}$ and $387.21 \mathrm{mg}$ $\mathrm{kg}^{-1}$ for zero hour, 14th day, 28th day, 42nd day and 56th day respectively. Abu and Akomah (2008) also reported that the Total Hydrocarbon Content (THC) lost in autoclaved control was not greater than $120 \mathrm{mg} \mathrm{kg}^{-1}$. This little amount of THC lost can be accounted for by natural attenuation process such as photo-oxidation, volatilization and evaporation. It is not surprising that at zero hour in all the experimental groups, there was no loss of either TPH or THC. This is because at the zero hour, microbial metabolism has not actually begun.

In Guanabara Bay, Marciel-Souza et al. (2006) reported a positive contribution of natural attenuation in reduction of total petroleum hydrocarbon, Polycyclic Aromatic Hydrocarbons (PAH's) in such mangrove sediments. Okoro (2010) studied bioremediation in Escravos mangrove swamp polluted by crude oil using NPK fertilizer. The scholar reported a decrease in the mean total petroleum hydrocarbon from $5360 \mathrm{ppm}$ to $2360 \mathrm{ppm}$ at zero hour to 5 th week of study respectively. It was reported that inclusion of biosurfactant established a significant biodegradation after 7 days of application of the biosurfactant and NPK oleophilic fertilizer. The use of water hyacinth recipe to make provision for limiting nutrient for the purpose of bioremediation has never been published by any known scholar. This means that this study is a pioneer and frontier bioremediation study using water hyacinth recipe/nutrient powder. In a related development, water hyacinth recipe produced using different approach from our method, was been successfully used in Pakistan for fish ponds fertilization in order to supply nutrients which will promote the growth of grasses for fish grazing in the pond (Widjajant et al., 2002). This study in Pakistan buttresses the fact that water hyacinth is nutrient rich (Widjajant et al., 2002). In Rwanda, water hyacinth recipe/fertilizer produced in a different procedure with our own recipe, was used to increase soil fertility and maize (Zea may) performance/output. In a 90 days study, it was observed that there was a significant increase in output maize in the water hyacinth recipe treated plot and no significance was statistically observed in the control which was not treated with water hyacinth recipe (Gashamura, 2009).

\section{CONCLUSION}

The results of this research study have shown that water hyacinth recipe/nutrient formula are effective in the supply of limiting nutrients necessary for bioremediation of crude oil impacted media such as mangrove soils. This cost effective fertilizer can be harnessed into preserved powdery forms and be used for bioremediation by Oil and Gas Companies. This study is a pioneer research on the use of water hyacinth powder for bioremediation calls for more research attention especially in field scales where factors such as tidal influence, emulsification cannot be eliminated and are better understood. The expanded scope will include enzymes profile studies during the remediation process. The long term aim of bioremediation design is to develop a cost effective and environmentally friendly approach. Water hyacinth powder apart from being cost effective is also environmentally friendly. These environmental friendly remedial actions are geared towards sustainable development in the Niger Delta.

\section{ACKNOWLEDGEMENT}

The Reseachers wish to thank the management of Shell Petroleum Development Company of Nigeria (SPDC) for providing Research Fund for the study in the form of one year Research Internship in her Environment Unit which was granted to the lead author. Mr. Ebikake Paul, a postgraduate student in the Department of Microbiology, University of Port Harcourt, Nigeria is greatly acknowledged for the painstaking and thorough statistics carried out in this study. 


\subsection{Dedication}

The study is dedicated to a family friend of the lead author; late Dr. Nnaukwu Ukoha, who died in July 2007, barely six weeks after his appointment as Secretary to Abia State Government of Nigeria.

\section{REFERENCES}

Abu, G.O. and O.N. Akomah, 2008. A laboratory assessment of anaerobic biodegradation of petroleum hydrocarbons in a typical Niger Delta Wetland. Global J. Pure Applied Sci., 14: 97-102.

Abu, G.O. and P.A. Ogiji, 1996. Initial test of a bioremediation scheme for the clean up of an oilpolluted waterbody in a rural community in Nigeria. Bioresources Technol., 58: 7-12. DOI: 10.1016/S0960-8524(96)00080-6

Adenipekun, C.O. and I.O. Fasidi, 2005. Bioremediation of oil-polluted soil by Lentinus subnudus, a Nigerian white-rot fungus. Afr. J. Biotechnol. Assoc. Crop Sci., 4: 796-798.

Amanchukwu, S.C., A. Obafemi and G.C. Okpokwasili, 1989a. Hydrocarbon degradation and utilization by a palm-wine yeast isolate. FEMS Microbiol. Lett., 57: 151-154. DOI: 10.1111/j.1574-6968.1989.tb03290.x

Amanchukwu, S.C., A. Obafemi and G.C. Okpokwasili, 1989b. Single-cell-protein production bySchizosaccharomyces pombe isolated from palmwine using hydrocarbon feedstocks. Folia Microbiol., 34: 112-119. DOI: 10.1007/BF02823688

Atlas, R.M. and R. Bartha, 1972. Degradation and mineralization of petroleum in sea water: Limitation by nitrogen and phosphorous. Biotechnol. Bioeng., 14: 309-318. DOI: 10.1002/bit.260140304

Atuanya, E.I. and I.N. Ibeh, 2004. Bioremediation of crude oil contaminated loamy-sand and clay soils. Nigerian J. Microbiol., 18: 6373-6386.

Barnett, H.L. and B.B. Hunter, 1972. Illustrated Genera of Imperfect Fungi. 3rd Edn., Burgress Publication Company, Minneapolis, Minn., pp: 241.

Chikere, B.O. and C.C. Chijioke-Osuji, 2006. Microbial diversity and physiochemical properties of a crude oilpolluted soil. Nigerian J. Microbiol., 20: 1039-1046.

Chikere, C.B., G.C. Okpokwasili and B.O. Chikere, 2009. Bacterial diversity in a tropical crude oilpolluted soil undergoing bioremediation. Afr. J. Biotechnol., 8: 2535-2540.

Chukwura, E.I., C.I. Nwokolo and S.C.U. Nwachukwu, 2005. Bioremediation of crude oil polluted Escravos River using Candida utilis. Nigerian J. Microbiol., 19: 623-630.
Das, K. and A.K. Mukherjee, 2007. Crude petroleum-oil biodegradation efficiency of Bacillus subtilis and Pseudomonas aeruginosa strains isolated from a petroleum-oil contaminated soil from North-East India. Bioresources Technol., 98: 1339-1345. DOI: 10.1016/j.biortech.2006.05.032

Eziuzor, C.S. and G.C. Okpokwasili, 2009. Bioremediation of hydrocarbon contaminated mangrove soil in a bioreactor. Nigerian J. Microbiol., 23: 1777-1791.

Gashamura, F.R., 2009. Effects of manure from water hyacinth on soil fertility and maize performance under controlled conditions in Rwanda. MS.c. Thesis, submitted to Swedish Biodiversity Center, Uppsala, Sweden.

Marciel-Souza, M.C., A.V., Macrae, A.G.T. Ferreira and L.C.M. Mendonca-Hagler, 2006. Chemical and microbiological characterization of mangrove sediments after oil spill in Guarnabara bay, RJ, Brazil. Brazilian J. Microbiol., 37: 1-8.

Mbakwem-Aniebo, C. and L.C. Ezekwem, 2010. Comparable etiology of tinea capitis in mgbuoba, rivers state akpulu, imo state. Nigeria. Nigerian J. Microbiol.

Mukherjee, A.K. and N.K. Bordoloi, 2010. Bioremediation and reclamation of soil contaminated with petroleum oil hydrocarbons by exogenously seeded bacterial consortium: A pilotscale study. Environ. Sci. Pollut. Res. Int., 18: 471478. DOI: $10.1007 / \mathrm{s} 11356-010-0391-2$

Nelson, D.W. and L.E. Sommers, 1975. A rapid and accurate method for estimating organic carbon in soil. Proc. Ind. Acad. Sci., 84: 456-462.

Obire, O., 1988. Studies on the biodegradation potentials of some microorganisms isolated from water systems of two petroleum producing areas in Nigeria. Nigerian J. Botany, 1: 81-90.

Odokuma, L.O. and A.A. Dickson, 2003. Bioremediation of a crude oil polluted tropical mangrove environment. J. Applied Sci. Environ. Manage., 7: 23-29.

Okoh, A.I. and M.R. Trejo-Hernandez, 2006. Remediation of petroleum hydrocarbon polluted systems: Exploiting the bioremediation strategies. Afr. J. Biotechnol., 5: 2520-2525.

Okolo, J.C., E.N. Amadi and C.T.I. Odu, 2005. Effects of soil treatments containing poultry manure in crude oil degradation in a sandy loam soil. Applied Ecol. Environ., 3: 47-53. 
Okoro, C.C., 2010. Enhanced Bioremediation of hydrocarbon contaminated mangrove swamp in the Nigerian oil rich Niger Delta using sea water microbial inoculate amended with crude oil biosurfactants and macronutrients. Nature Sci., 8: 195-206.

Okpokwasili, G.C. and S.C. Amanchukwu, 1988. Petroleum hydrocarbon degradation by Candida species. Environ. Int., 14: 243-247. DOI: 10.1016/0160-4120(88)90145-6

Osuji, L.C. and P.E. Ezebuiro, 2006. Hydrocarbon contamination of a typical mangrove floor in Niger Delta, Nigeria. Int. J. Environ. Sci. Technol., 3: 313320.

Oudot, J.P., M.V. Fussey, J.P. Vanpract and F. Gail, 1981. Hydrocarbon weathering in seashore invertebrates and sediments over a two year period following the Amoco Cadiz oil spill: Influence of microbial metabolism. Environ. Pollut. Series, 26: 93-110. DOI: 10.1016/0143-1471(81)90040-4

Rahman, K.S.M., T.J. Rahman Y. Kourkoutas, I. Petsas and I.M. Banat, 2003. Enhanced bioremediation of n-alkane in petroleum sludge using bacterial consortium amended with rhamnolipid and micronutrients. Bioresources Technol., 90: 159-168. DOI: $10.1016 / \mathrm{S} 0960-8524(03) 00114-7$
Saari, E., P. Peramaki and J. Jalonen, 2007. A comparative study of solvent extraction of total petroleum hydrocarbons in soil. Microchim. Acta, 158: 261-268. DOI: 10.1007/s00604-006-0718-3

UNEP, 2004. United Nations Environmental Programme, Analytical Methods for water quality. Burllinton Publishing House, Ontario, Canada.

Vandermeulen, J.H. and E.S. Gilfillan, 1985. Petroleum, Pollution, corals and mangroves. Marine Technol. Soc. J., 18: 11-16.

Widjajant, D.W., T. Honmura and N. Miyauchi, 2002. Nitrogen release from green manure of water hyacinth in rice cropping systems. Pak. J. Biol. Sci., 5: 740-743.

Zhu, X., A.D. Venosa, M.T. Suidan and K. Lee, 2001. Guidelines for the bioremediation of marine shorelines and freshwater wetlands. U.S. Environmental Protection Agency, Cincinnati, OH. 